\title{
Article \\ Effects of Air Supply Terminal Devices on the Performance of Variable Refrigerant Flow Integrated Stratum Ventilation System: An Experimental Study
}

\author{
Yat Huang Yau ${ }^{1,2, * \mathbb{D}}$, Umair Ahmed Rajput ${ }^{1,2,3} \mathbb{D}$, Altaf Hussain Rajpar ${ }^{4}$ and Natalia Lastovets ${ }^{5}$ \\ 1 Department of Mechanical Engineering, Faculty of Engineering, University of Malaya, \\ Kuala Lumpur 50603, Malaysia; engr.umair@quest.edu.pk \\ 2 UM-Daikin Laboratory, Department of Mechanical Engineering, Faculty of Engineering, University of Malaya, \\ Kuala Lumpur 50603, Malaysia \\ 3 Department of Mechanical Engineering, Quaid-e-Awam University of Engineering, Science and \\ Technology (QUEST), Nawabshah 67480, Pakistan \\ 4 Department of Mechanical Engineering, College of Engineering, Jouf University, Sakaka 42421, Saudi Arabia; \\ altafrajpar@gmail.com \\ 5 Civil Engineering Unit, Tampere University, 33720 Tampere, Finland; natalia.lastovets@tuni.fi \\ * Correspondence: yhyau@um.edu.my; Tel.: +603-79675210; Fax: +603-79675317
}

check for

updates

Citation: Yau, Y.H.; Rajput, U.A.;

Rajpar, A.H.; Lastovets, N. Effects of Air Supply Terminal Devices on the Performance of Variable Refrigerant Flow Integrated Stratum Ventilation System: An Experimental Study. Energies 2022, 15, 1265. https:// doi.org/10.3390/en15041265

Academic Editors: Matilde Santos and Giorgio Ficco

Received: 27 December 2021

Accepted: 1 February 2022

Published: 9 February 2022

Publisher's Note: MDPI stays neutral with regard to jurisdictional claims in published maps and institutional affiliations.

Copyright: (C) 2022 by the authors. Licensee MDPI, Basel, Switzerland. This article is an open access article distributed under the terms and conditions of the Creative Commons Attribution (CC BY) license (https:// creativecommons.org/licenses/by/ $4.0 /)$.

\begin{abstract}
A variable refrigerant flow integrated stratum ventilation (VRF-SV) system was proposed as an energy efficient substitute for conventional central cooling systems for buildings. The novel system provided conditioned air to enclosed spaces with high indoor air quality and thermal comfort. This study investigated the effects of different types of ASTDs on the performance of the VRF-SV hybrid system. The performance was experimentally evaluated with five air terminal types, including bar grille, double deflection grille, jet slot, perforated and drum louver diffusers. The evaluation was carried out using standard indices: temperature and velocity distribution, airflow pattern, effective draft temperature (EDT), air distribution performance index (ADPI), thermal sensation vote and comfort feedback survey. The results indicated that the ASTD type had a significant impact on airflow pattern. Furthermore, the bar grille diffuser provided the occupants with greater thermal comfort and acceptable indoor environment. Almost all the EDT values determined in the breathing zone in the case with bar grille diffuser found under the satisfactory range, i.e., $-1.2<\mathrm{K}<1.2$. Based on these values, the ADPI for bar grille diffuser was calculated as $92.8 \%$. Thus, the bar grille diffuser is recommended to be installed with the VRF-SV hybrid system in buildings.
\end{abstract}

Keywords: VRF-SV hybrid system; air supply terminal device (ASTD); air diffusion performance index (ADPI); airflow pattern; thermal comfort

\section{Introduction}

Increasing concerns about high indoor air quality (IAQ) and excessive energy use in built environments [1,2] demand continuous development of efficient air conditioning and mechanical ventilation (ACMV) systems. ACMV systems in buildings are utilized to remove excess heat from indoor spaces and to replace polluted indoor air with fresh outdoor air. As the major shareholder of a building's energy consumption, an ACMV system is comprised of two different systems: the air conditioning system and the mechanical ventilation system [3]. The two systems account for more than $60 \%$ of the overall energy consumption in buildings [4]. The most common central ACMV systems are chiller-based cooling systems and variable refrigerant flow (VRF) system.

The VRF systems have grown more popular in buildings as a viable substitute to conventional central chiller-based systems due to their higher part load energy efficiency and individualized thermal control [5]. However, the VRF systems perform worse when it 
comes to providing fresh outdoor air for ventilation and buildings installed with these systems struggle to maintain the desired IAQ. A recent study reported that poor IAQ and low temperature air recirculation in rooms could enhance the spread of SARS-CoV-2 virus [6]. Thus, to overcome the ventilation deficiency, VRF systems have been integrated with different mechanical ventilation systems for efficient ACMV solutions for buildings [7-9].

As an energy efficient alternative to more commonly used mechanical ventilation systems, i.e., mixing ventilation (MV) and displacement ventilation (DV), stratum ventilation (SV) was proposed in 2009 [10] to address higher energy consumption issues in ACMV systems [11]. It exhibited superior thermal comfort (TC), enhanced IAQ and higher energy saving potential $[12,13]$. In SV air distribution systems, conditioned outdoor air (OA) at elevated temperature and velocity is supplied directly to the occupied zone through wall-mounted air supply terminal devices (ASTDs) $[12,14]$. The recently proposed VRF-SV hybrid system integrated both of these efficient systems to take advantage of their synergic benefits. The hybrid system was designed with an aim to reduce the higher energy needs of ACMV systems, while improving IAQ and TC.

The literature study revealed that airflow patterns generated by ACMV systems have a huge impact on room IAQ and occupant TC $[15,16]$. Furthermore, the airflow pattern in a room is driven by many factors, such as the ASTD type and number, position layout, building envelope, flowrate and temperature of the supply air [17-19]. A great deal of research work has been carried out to investigate the impact of the geometry of the air terminal devices on the airflow pattern [20]. Nielsen [21] worked on the airflow distribution in a room to ensure the occupants' thermal comfort. The findings concluded that the room airflow pattern, originated through an air terminal device, influenced thermal comfort significantly. A similar study was performed by Kalmar [22] under personalized ventilation using different types of ASTDs. The results suggested that the adaptation of different geometries for ASTDs improved the thermal conditions of the ventilated zone. $\mathrm{Hu}$ [23] investigated the airflow characteristics of the vortex diffuser using experimental and numerical methods. The study revealed that the flow pattern near the diffuser was 3-dimensional and highly turbulent. It also showed that a vortex diffuser had a higher room entrainment ratio than a circular type multi-cone diffuser. Entrainment ratio is a jet characteristic, commonly used to evaluate the airflow throw from the diffuser face [24]. In another study, Nastase et al. [25], using the mixing ventilation method, compared a lobed grille with a standard grille. They found that the lobed grille provided better airflow distribution, and thus improved indoor thermal comfort. Other studies reported the impacts of lip and blade angles of different types of diffusers on the room airflow pattern [26,27].

The studies reviewed above highlighted the importance of the ASTD type on the air distribution performance of the ACMV systems. Furthermore, ASTDs are usually selected based on jet throw data provided by the diffuser manufacturers. The manufacturers collect the data by treating the uniform jet outflow from the diffuser. However, the air jet flows from the diffuser are affected by many factors. In most cases, the diffusers are connected to the ventilation duct by plenum boxes [28] installed above the suspended ceilings or outside of the side walls, depending on type of the diffuser applied. Plenum boxes are designed with top, bottom or side collars for air supply inflow [29]. For ceiling-mounted diffusers, the air outflow from the diffuser created better room entrainment when the collar was attached at the top surface of the plenum box compared to when the collar was at the side surfaces. This was due to the creation of large numbers of air vortices in the plenum box with side collar orientation; they provided a uniform jet throw. However, the selection of the plenum and the collar orientation is usually performed by looking at the installation space, which may affect the uniformity of the jet outflow [29].

To the best of authors' knowledge, only very limited studies on the effects of ASTD types, geometry and layouts exist in the open literature for SV air distribution system [30-33]. No study found conducted research on the effects of ASTD on air distribution performance when SV was combined with a VRF system. This research was therefore designed with an 
aim to investigate the effects of different types of ASTDs on the performance of a novel VRF-SV hybrid system. This research had two main objectives. The first objective was to study the impacts of top, side and bottom orientations of plenum collars on jet outflows from the ASTD. In the second objective, the effects of five different types of ASTDs on the thermal comfort and air distribution performances of the VRF-SV hybrid system were investigated. Additionally, quantitative analyses of the hybrid system's effective draft temperature (EDT) and air distribution performance indices (ADPI) of the five ASTDs were formulated. For the visualization of flow pattern driven by the selected ASTDs, smoke tests were carried out. Thermal sensation votes and comfort surveys were also conducted with different types of ASTDs installed in a meeting room environment.

\section{VRF-SV Hybrid System-A Brief Overview}

A novel attempt was made by the authors of this paper to combine a VRF system with a stratum ventilation (SV) air distribution system. Different design approaches were adopted under the project to enhance the broad application of the combined system. In the decoupled design method, the two systems were combined to achieve their tasks separately, as seen in Figure 1a. The VRF indoor terminal unit handled the sensible load, whereas the outdoor air processing unit (DOAS) was used to treat the minimum required outdoor air for ventilation (ASHRAE 62.1 [34]). The fully conditioned outdoor air was then supplied into the space through ASTDs to attain the latent load.
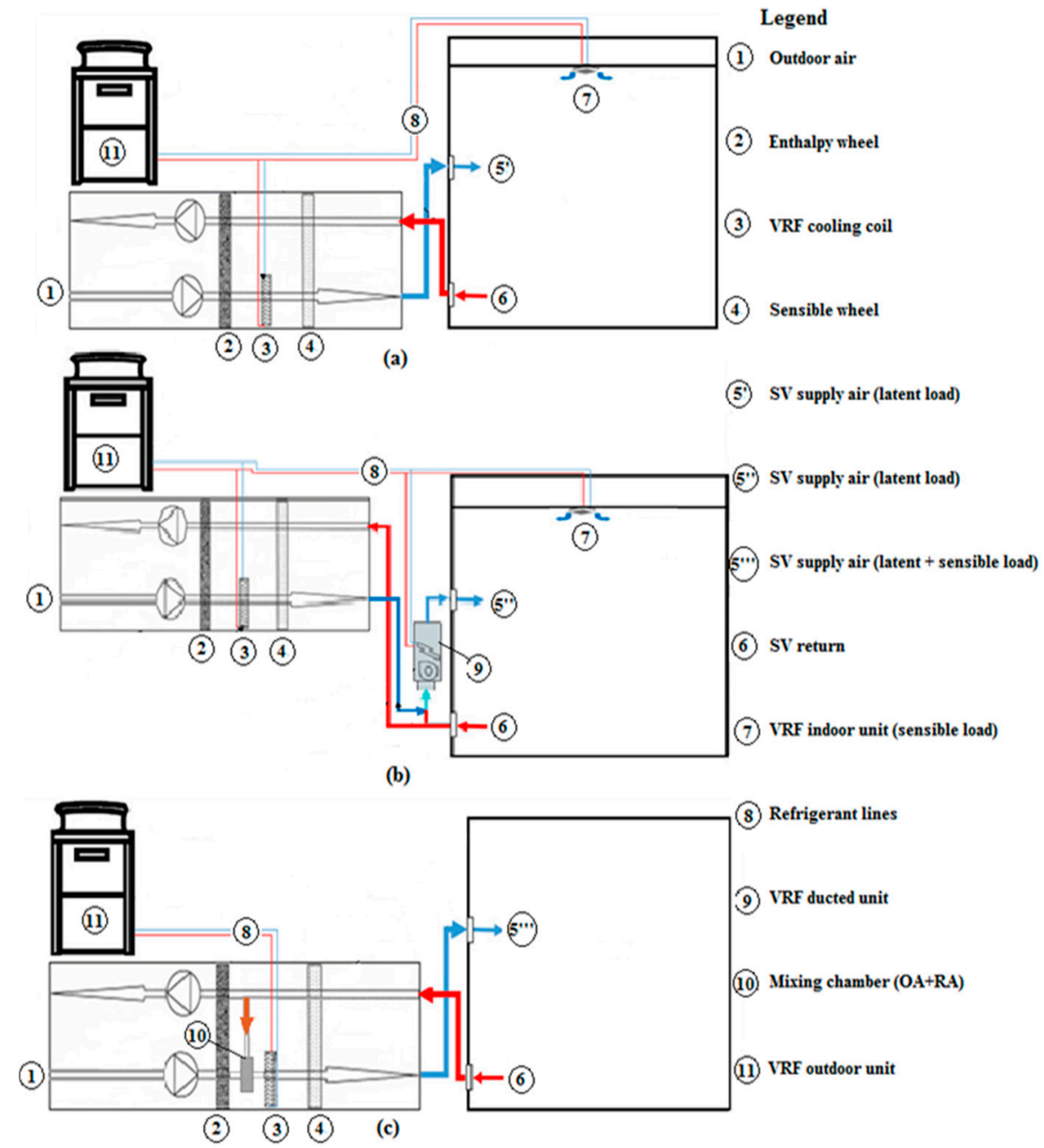

Figure 1. VRF integrated stratum ventilation (VRF-SV) system (a) decoupled design (b) integrated design (c) fully integrated design. 
The outdoor air was pretreated through DOAS prior to delivery to the target space in the integrated approach. First, preconditioning was done to remove both the sensible and latent loads from the outdoor air. The pretreated air from DOAS was then delivered into the return air duct of the VRF ducted unit, as shown in Figure 1b. One major drawback of this method was that, if failure were to occur in the air handling equipment, the terminal system must be capable enough to bear the extra load of OA to avoid any loss in the controlled thermal environment [35].

Figure 1c shows another novel method of integrating the VRF system with the DOAS system in order to supply fully conditioned air directly into the space using stratum ventilation. In this method, conditioned air at an elevated temperature is provided to cater to the total heat load of the space. No separate VRF indoor terminal is required in this design. This design approach reduces the overall system capacity and overcomes the large space requirement for the combined system installation.

\section{Methodology}

The methodology adopted in this study was mainly divided into four stages. In the first stage, the ASTDs were selected based on their application suitability to be installed as SV air terminals on the side wall of the experimental chamber. In the next stage, detailed experimental work was performed. For this purpose, the experimental setup was established and measurements were carried out. To study the effects of ASTDs on thermal comfort and air distribution performance of the VRF-SV system, several standard parameters $[32,33,36]$ were evaluated in the third stage. Subsequently, in the last stage, bias uncertainty analysis was performed to estimate the accuracy of the experimentally measured data.

\subsection{Selection of ASTDs}

In total, five types of commonly used air supply terminal devices were studied. These are all shown in Figure 2. Different cases with these air terminal devices were studied under constant airflow rate. Considering the fact that exhaust terminal type had an insignificant impact on the airflow pattern [30], the bar grille diffuser was used as an exhaust terminal in all studied cases. The supply air terminals were installed on the side wall at $1.9 \mathrm{~m}$ height and the return/exhaust terminal at $0.33 \mathrm{~m}$ height from floor. These heights were selected based on the design guidelines devised for the stratum ventilation system [37]. The indoor design temperature and the walls' internal temperatures were all set to $26^{\circ} \mathrm{C}$, which were strictly monitored and adjusted by the locally installed thermal sensor (room thermostat). The detailed experimental parameters and the diffusers' dimensions are shown in Table 1.

Table 1. Details of the initial/boundary parameters.

\begin{tabular}{cccccc}
\hline Case & Diffuser Type & $\begin{array}{c}\text { Diffuser Size } \\
(\mathbf{m m})\end{array}$ & Airflow Rate & $\begin{array}{c}\text { Supply Temperature } \\
\left({ }^{\circ} \mathbf{C}\right)\end{array}$ & $\begin{array}{c}\text { Room Temperature } \\
\left({ }^{\circ} \mathbf{C}\right)\end{array}$ \\
\hline 1 & Bar grille diffuser & $500 \times 300$ & $0.25 \mathrm{~m}^{3} / \mathrm{s}$ & $18.7 \pm 0.3$ & $26.0 \pm 0.1$ \\
\hline 2 & Perforated diffuser & $500 \times 300$ & $0.25 \mathrm{~m}^{3} / \mathrm{s}$ & $18.5 \pm 0.2$ & $26.0 \pm 0.2$ \\
\hline 3 & Double deflection grille & $500 \times 300$ & $0.25 \mathrm{~m}^{3} / \mathrm{s}$ & $18.5 \pm 0.1$ & $26.0 \pm 0.1$ \\
\hline 4 & Drum louver diffuser & $500 \times 300$ & $0.25 \mathrm{~m}^{3} / \mathrm{s}$ & $18.8 \pm 0.3$ & $26.0 \pm 0.1$ \\
\hline 5 & Jet slot diffuser & $1000 \times 135$ & $0.25 \mathrm{~m}^{3} / \mathrm{s}$ & $19.0 \pm 0.1$ & $26.0 \pm 0.1$ \\
\hline
\end{tabular}




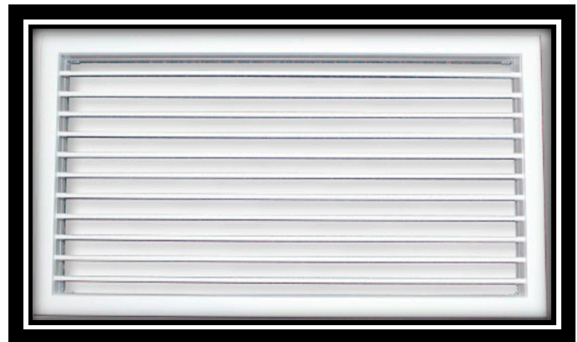

(a)

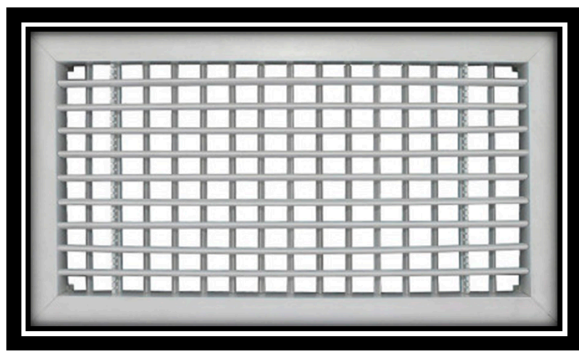

(c)

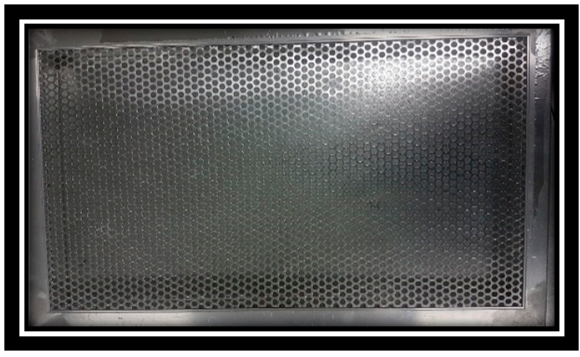

(b)

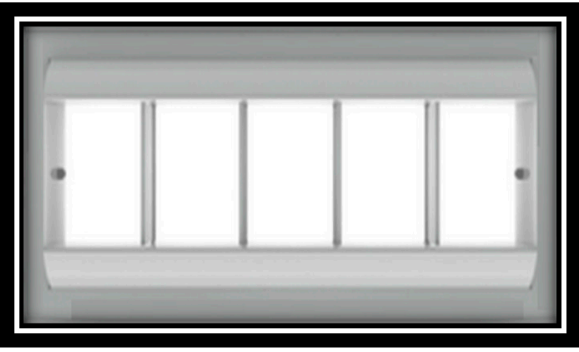

(d)

(e)

Figure 2. Types of supply air terminals: (a) bar grille (b) perforated diffuser (c) double deflection grille (d) drum louver and (e) jet slot diffuser.

\subsection{Experimentations}

To investigate the effects of ASTDs installed with the novel VRF-SV hybrid system, the experiments were carried out in an air diffuser testing laboratory at Prudentaire Engineering Private Ltd. (Seri Kembangan, Malaysia). The laboratory was located at the core of a building with no boundary wall exposed to solar radiation. Thus, the walls' internal surface temperatures were controlled by adjusting the surrounding ambient temperature to the same value, i.e., $26{ }^{\circ} \mathrm{C}$ (room design temperature), so that the adiabatic condition was achieved with no heat flow in and out of the testing chamber. The laboratory was $6.0 \mathrm{~m}$ in length, $5.4 \mathrm{~m}$ in width and $2.74 \mathrm{~m}$ in height. The plenum box collar orientations, experimental chamber and air conditioning system setup are shown in Figure 3. Prior to starting experimentation, the heat load of the laboratory was measured; the calculated details are shown in Table 2.

Table 2. Calculated thermal Load.

\begin{tabular}{|c|c|c|c|c|c|}
\hline & \multirow{2}{*}{ Entity } & \multirow{2}{*}{ People } & \multicolumn{3}{|c|}{ Other Heat Sources } \\
\hline & & & Computer & Equipment & Lighting \\
\hline \multirow{2}{*}{$\begin{array}{l}\text { Heat } \\
\text { Load }\end{array}$} & $\begin{array}{l}\text { Testing chamber } \\
\text { (for ASTD testing) }\end{array}$ & $\begin{array}{c}70 \mathrm{~W} \\
=2 \times 70=140 \mathrm{~W}\end{array}$ & \multirow[t]{2}{*}{$2 \times 90=180 W$} & \multirow[t]{2}{*}{$500 \mathrm{~W}$} & \multirow[t]{2}{*}{$100 \mathrm{~W}$} \\
\hline & $\begin{array}{c}\text { Meeting Room } \\
\text { (for comfort survey) }\end{array}$ & $\begin{array}{c}70 \mathrm{~W} \\
=10 \times 70=700 \mathrm{~W}\end{array}$ & & & \\
\hline
\end{tabular}

In the air distribution side of the VRF-SV system, an insulated flexible duct of diameter $200 \mathrm{~mm}$ was attached to the oval-shaped collar of the plenum box. The plenum box was sized as per the geometry of the ASTD type. A smoke generator was also employed to visualize the airflow pattern. The smoke was supplied into the flexible duct after controlling 
the flowrate through the VAV damper. To comply with the principle of comparison, all the cases were investigated under similar settings.

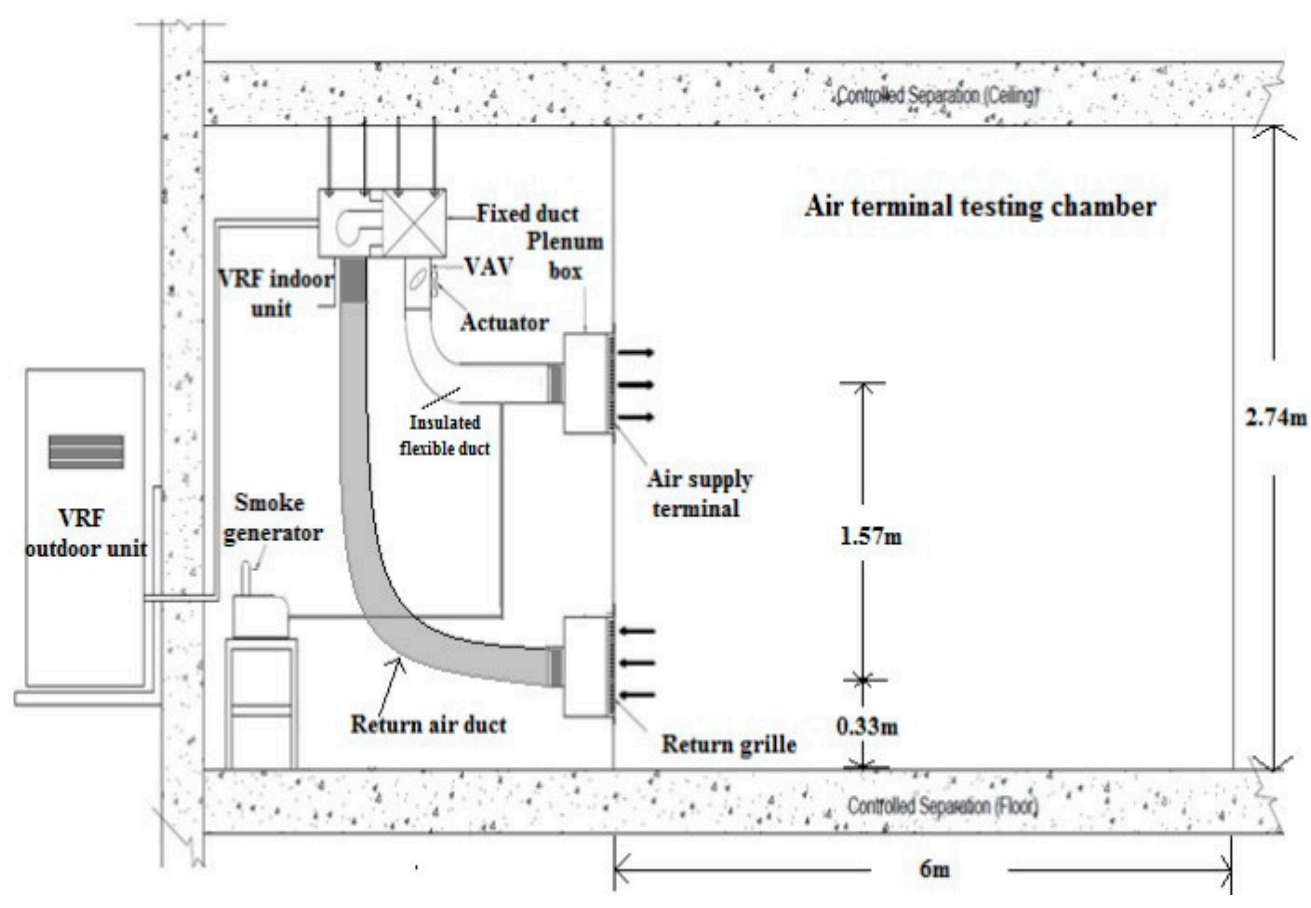

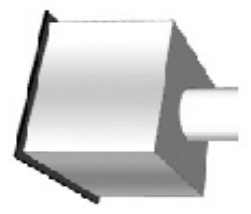

Front collar

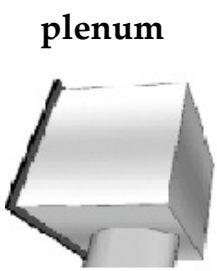

Bottom collar plenum

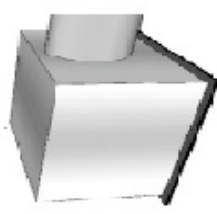

Top collar

plenum

Figure 3. Experimental chamber setup and plenum boxes with front, bottom and top collar orientation.

Measurement Methods and Equipment

Detailed environmental conditions of the laboratory were measured before the actual testing started. The temperatures of all the internal surfaces were checked using the HANNA HI 147-00 surface temperature measuring tool. The airflow rate-at room level, at the face of the ASTD—was measured and monitored by ZTH-VAV belimo device. The Alnor 440-A hot wire anemometer (seen in Figure 4) was used to measure the indoor temperature at different locations for the determination of the room average. The accuracy of the anemometer was $\pm 0.3{ }^{\circ} \mathrm{C}$ for temperature, $0.015 \mathrm{~m} / \mathrm{s}$ for velocity and $\pm 3 \%$ for relative humidity (RH). The actual measurements were taken every $1 \mathrm{~h}$ after the VRF began delivering air at full fan capacity with a fluctuation of less than $5 \%$. At the 4 th hour of fan operation, the room achieved steady-state condition, when the mean air temperatures at the supply inlet, return outlet, and at the center of the room did not exceed more than $1{ }^{\circ} \mathrm{C}$ variation (Yau et al., 2018). The difference in the room's internal surface temperatures was also recorded below $0.1{ }^{\circ} \mathrm{C}$ during that period. This was all done to make the environment behave as nearly isothermally as possible. The experimental setup in the testing chamber and the measuring line locations are shown in Figure 5. 


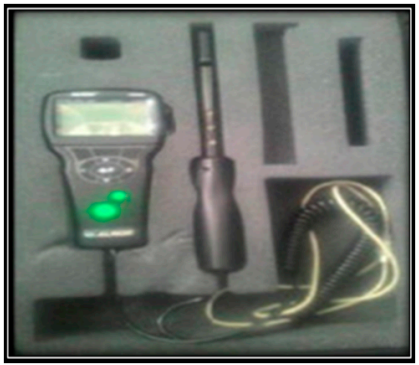

(a)

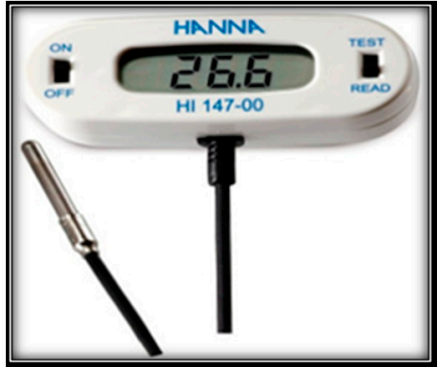

(b)

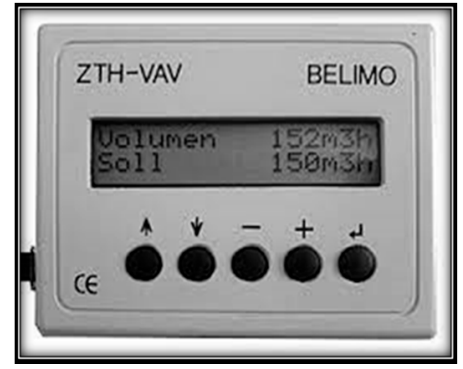

(c)

Figure 4. (a) Alnor 440-A hot wire anemometer (b) HANNA HI 147-00 surface temperature measuring tool (c) ZTH-VAV belimo pressure adjustment device.

\section{Air supply terminal device}

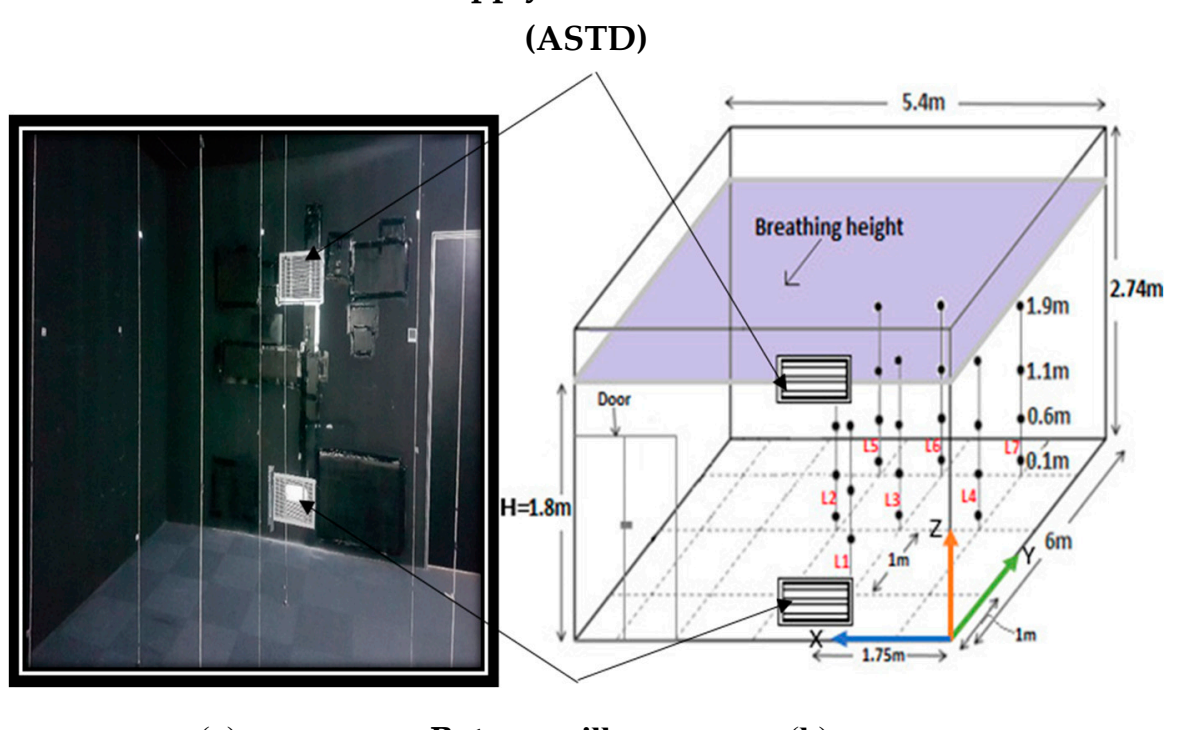

(a)

Return grille

(b)

Figure 5. (a) Experimentation in the testing chamber (b) The layout and measurement locations.

\subsection{Evaluation Criteria}

This study investigated the performance of different air distribution terminals (ASTDs) using the following indices:

1. Temperature field distribution

2. Velocity distribution

3. Airflow throw

4. Effective draft temperature (EDT) and air distribution performance index (ADPI)

5. Airflow pattern

6. Thermal sensation and comfort feedback

Koestel and Tuve [18] investigated the effects of airflow velocity and temperature on human thermal comfort. They also defined the air draft (Effective Draft) as any localized feeling of coldness or warmth on any part of the body caused by the combined effect of air velocity and temperature, while the humidity and radiation remained constant. To determine the effective draft temperature (EDT, $\theta_{\text {edt }}$ ) for stratum ventilation, Lin et al. [38] developed an equation, shown as Equation (1).

$$
\theta_{\text {edt }}=\left(T_{x}-T_{c}\right)-\left(V_{x}-1.1\right)
$$

where,

$\theta_{\text {edt }}=$ Effective draft temperature, $\mathrm{K}$ 
$T_{x}=$ Local air DB temperature, ${ }^{\circ} \mathrm{C}$

$T_{\mathcal{C}}=$ Mean DB temperature of the room, ${ }^{\circ} \mathrm{C}$

$V_{x}=$ Local air stream speed, $\mathrm{m} / \mathrm{s}$

For stratum ventilation air distribution, the ranges defined for good and satisfactory thermal comfort conditions at velocity $<0.8 \mathrm{~m} / \mathrm{s}$ were $-0.6 \mathrm{~K}<\theta_{\text {edt }}<0.6 \mathrm{~K}$ and $-1.2 \mathrm{~K}<$ $\theta_{\text {edt }}<1.2 \mathrm{~K}$, respectively. The ADPI was defined in percentages, in which the measurements taken in an occupied space where the effective draft temperature found within the range mentioned above to the measurements taken in total. The most desirable condition for an efficient air distribution system occurs if the ADPI approaches 100\%, whereas the ADPI must not be less than $80 \%$ in a good air distribution system [39]. The expression for ADPI is given below,

$$
\operatorname{ADPI}(\%)=\frac{\left(N_{\theta} \times 100\right)}{N}
$$

where,

$\theta_{\text {edt }}=$ Effective draft temperature, $\mathrm{K}$,

$N_{\theta}=$ Points measured in the occupied space that falls within $-1.2 \mathrm{~K}<\theta_{\text {edt }}<1.2 \mathrm{~K}$, and $N=$ Total points measured in the occupied space.

The laboratory chamber was converted into the meeting room to conduct the thermal sensation and comfort survey, as shown in Figure 6. The thermal load calculated for the meeting room was presented earlier (Table 2). A total of 10 subjects ( 4 female and 6 male) were formally hired for the survey-based tests in order to investigate the effects of ASTDs on human thermal sensation and comfort. All those subjects were from the office staff and were young and healthy. They were all active in the discussion during the meeting and did not do any tiring activity before the experiments started. The tests were conducted during their break hours and took around 2 weeks for complete data collection. The subjects all wore short or long-sleeved thin cotton shirts and trousers, with a clothing value limited to 0.5 clo $\left(0.078 \mathrm{~m}^{2} \mathrm{~K} / \mathrm{W}\right)$. Considering the meeting room environment with discussion process going on, the activity level chosen was 1.2 met. The complete anthropometric description of the subjects is presented in Table 3. On average, 30 minutes after establishing the steady state conditions in the meeting room, the experiments were conducted for selected ASTDs. The survey was completed by adopting a questionnaire (Appendix A) containing two questions based on the ASHRAE's 7-point scale thermal sensation vote (TSV) and thermal comfort vote (TCV), as mentioned in Table 4.

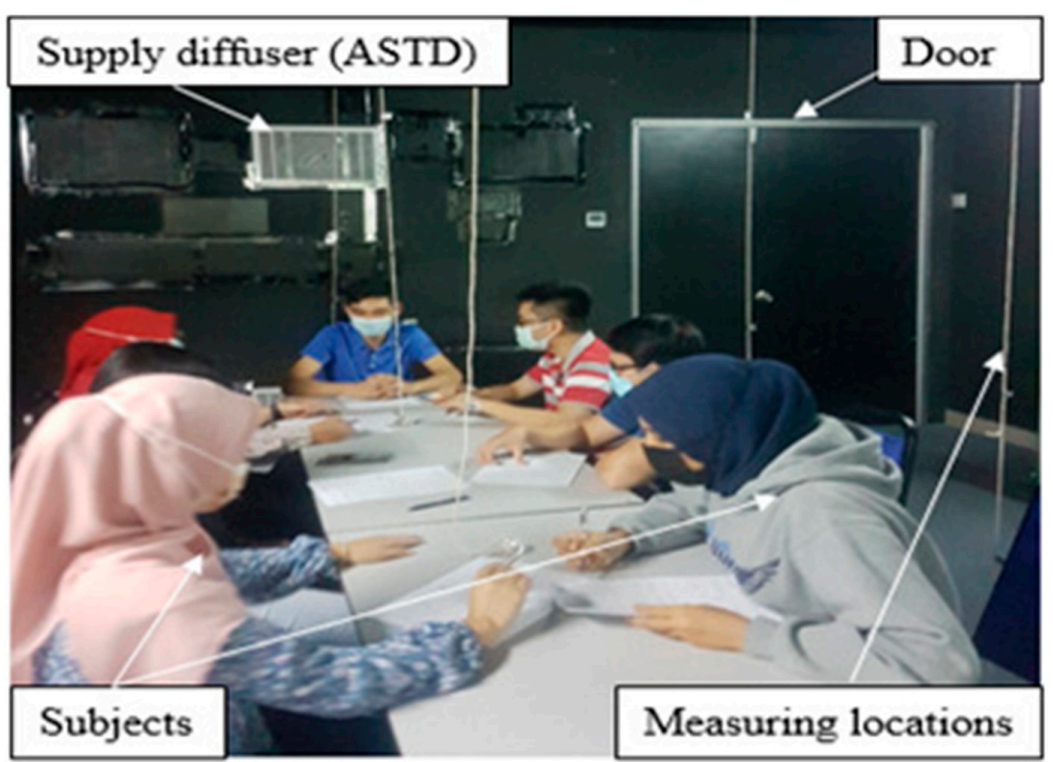

Figure 6. Meeting room environment. 
Table 3. Details of the experimental parameters.

\begin{tabular}{ccccccc}
\hline \multirow{2}{*}{ Index } & \multicolumn{2}{c}{ Female $(\boldsymbol{n}=\mathbf{4})$} & \multicolumn{2}{c}{ Male $(\boldsymbol{n}=\mathbf{6})$} & \multicolumn{2}{c}{ Total $(\boldsymbol{n}=\mathbf{1 0})$} \\
\cline { 2 - 7 } & \multicolumn{2}{c}{ Mean \pm SD Range } & \multicolumn{2}{c}{ Mean \pm SD Range } & \multicolumn{2}{c}{ Mean \pm SD Range } \\
\hline Age $($ years $)$ & $26.5 \pm 2.0$ & $25-30$ & $28.8 \pm 2.8$ & $25-33$ & $27.9 \pm 2.8$ & $25-33$ \\
\hline Height $(\mathrm{m})$ & $1.55 \pm 0.04$ & $1.5-1.62$ & $1.67 \pm 0.08$ & $1.62-1.81$ & $1.62 \pm 0.08$ & $1.5-1.81$ \\
\hline Body mass $(\mathrm{kg})$ & $57 \pm 1.4$ & $55-58$ & $66.2 \pm 9.0$ & $51-78$ & $62.5 \pm 8.3$ & $51-78$ \\
\hline BMI $^{*}\left(\mathrm{~kg} / \mathrm{m}^{2}\right)$ & $23.55 \pm 1.5$ & $21.5-25.8$ & $23.7 \pm 2.9$ & $18.7-27.1$ & $23.63 \pm 2.4$ & $18.7-27.1$ \\
\hline BSA ** $\left(\mathrm{m}^{2}\right)$ & $1.57 \pm 0.02$ & $1.55-1.60$ & $1.75 \pm 0.1$ & $1.53-1.94$ & $1.68 \pm 0.1$ & $1.53-1.94$ \\
\hline * Body mass index $(\mathrm{BMI})=\left(\mathrm{W} / \mathrm{H}^{2}\right) \times 104 * *$ & $*$ Body &
\end{tabular}

* Body mass index $(\mathrm{BMI})=\left(\mathrm{W} / \mathrm{H}^{2}\right) \times 104 .{ }^{* *}$ Body surface area $(\mathrm{BSA})=(\mathrm{W} 0.425 \times \mathrm{H} 0.725) \times 0.007184$.

Table 4. Details of the experimental parameters.

\begin{tabular}{clcc}
\hline TSV Scale & \multicolumn{1}{c}{ Meaning } & TCV Scale & Meaning \\
\hline-3 & Cold & 0 & Comfortable \\
-2 & Cool & +1 & Slightly \\
-1 & Slightly cool & +2 & uncomfortable \\
0 & Neutral & +3 & Uncomfortable \\
+1 & Slightly warm & & \\
+2 & Warm & & \\
+3 & Hot & & \\
\hline
\end{tabular}

\subsection{Bias Uncertainty Analysis}

Bias uncertainty analysis, sometimes known as error analysis, is a statistical technique used to evaluate the amount of uncertainty present in any experimental data. The bias uncertainty $(\Delta x)$ is the deviation of the measured value from the true value and calculated using Equation (3) [40].

$$
\Delta x=\frac{\mathrm{R}}{2}
$$

where $\mathrm{R}$ is the range and can be determined by taking difference between maximum and minimum values of the experimental data $(x)$.

$$
\mathrm{R}=x_{\max }-x_{\min }
$$

The uncertainty between measured and true value can then be converted into percentage uncertainty using Equation (3).

$$
\text { Percentage uncertainty }(\%)=\left(\frac{\Delta x}{\bar{x}} \times 100\right)
$$

where $\bar{x}$ is the mean of the measured values for single experimental reading.

The bias uncertainty analyses performed for the current study are presented in Table A1 (Appendix B). Restricted by the table length and width, the analysis was carried out for two height locations $(0.6 \mathrm{~m}$ and $1.1 \mathrm{~m}$ from the ground). The errors found in the velocity and temperature measurements indicated that the uncertainty was there in the collected data. However, the primary aim of this study was to evaluate the effects of ASTDs on the VRF-SV system performance, so high precision in the collected data was not the authors' objective. Moreover, the data were collected at multiple locations in the room and at different heights using a handheld measurement device. Therefore, bias uncertainty analysis was essential to check the acceptability of the error present in the collected data. The percentage uncertainty in the mean airflow velocity (as seen in Table A1) was in the range of $8.47 \%$ to $108.33 \%$ in the case with a bar grille, $9.61 \%$ to $95.45 \%$ in the case with double deflection grille, $11.53 \%$ to $150 \%$ with the perforated diffuser case, $10.29 \%$ to $150 \%$ with the drum louver diffuser and $0 \%$ to $150 \%$ for the jet slot diffuser case. The higher percentage of error in the collected data may be due to the low airflow rate 
at the measuring locations, as Hashemian et al. [41] determined that the low air velocity $(<0.5 \mathrm{~m} / \mathrm{s})$ significantly reduced the sensitivity.

The bias uncertainties calculated for temperature distributions at the measuring locations were in the range of $0-0.85 \%, 0-7.51 \%, 0-7.44 \%, 0-1.39 \%$ and $0-1.29 \%$ for the cases with bar grille, double deflection grille, perforated, drum louver and jet slot diffusers, respectively. As seen in Table 5, the bias uncertainty for all the diffuser types was relatively insignificant. This may have been due to the more uniform temperature distribution compared to the velocity distribution within the breathing zone. However, these results suggested that low to high numbers of uncertainties were present during field work measurements for all types of ASTDs.

Table 5. ADPI value for studied ASTDs.

\begin{tabular}{cccccc}
\hline ASTD & Bar Grille & $\begin{array}{c}\text { Perforated } \\
\text { Diffuser }\end{array}$ & $\begin{array}{c}\text { Double } \\
\text { Deflection Grille }\end{array}$ & $\begin{array}{c}\text { Drum Louver } \\
\text { Diffuser }\end{array}$ & $\begin{array}{c}\text { Jet Slot } \\
\text { Diffuser }\end{array}$ \\
\hline ADPI & $92.8 \%$ & $78.6 \%$ & $64.3 \%$ & $71.4 \%$ & $28.5 \%$ \\
\hline
\end{tabular}

\section{Results and Discussion}

\subsection{Effect of the Plenum Collar Orientation on Jet Outflow}

As seen in Figure 7, the temperature and velocity distributions showed similar patterns with front, top and bottom collar orientations at heights $0.1 \mathrm{~m}$ and $1.9 \mathrm{~m}$ from the floor. This indicated that different types of collar orientation did not greatly influence the regions near the floor and at the diffusers' mid-level heights. Moreover, the highest deviation in velocity values was noted with a front orientation at location 4, which was around $33.3 \%$ and $50.0 \%$ higher than the top and bottom orientations, respectively. Similarly, a maximum of $1{ }^{\circ} \mathrm{C}$ temperature difference was observed throughout the measurement locations. However, at height $\mathrm{y} / \mathrm{H}=0.6 \mathrm{~m}$ and $1.1 \mathrm{~m}$, a non-uniform distribution of temperature and velocities was seen. The lowest temperature of about $21.8^{\circ} \mathrm{C}$ was recorded at location $\mathrm{L} 4$ (at $0.6 \mathrm{~m}$ height) with the bottom orientation of the plenum collar. It may have been due to considerably uniform air supply conditions in this case. In terms of velocity distribution, the highest deviation recorded for the case with the front collar was at location L7, which is about $0.12-0.45 \mathrm{~m} / \mathrm{s}$ higher than the top collar and $0.16-0.5 \mathrm{~m} / \mathrm{s}$ higher than the bottom collar orientations. Similar results can also be found in reference [42] for the top and side entries of the plenum box. Therefore, based on the obtained results, front collar orientation was considered in this study to investigate the effects of ASTDs on the performance of the VRF-SV hybrid system.

\subsection{Effect of ASTDs on Air Distribution Performance}

In order to investigate the effects of ASTDs on the performance VRF-SV hybrid system, the temperature and velocity distributions at different heights and locations were measured. The subsequent sections will explain the behavior of evaluated parameters against ASTD type. 

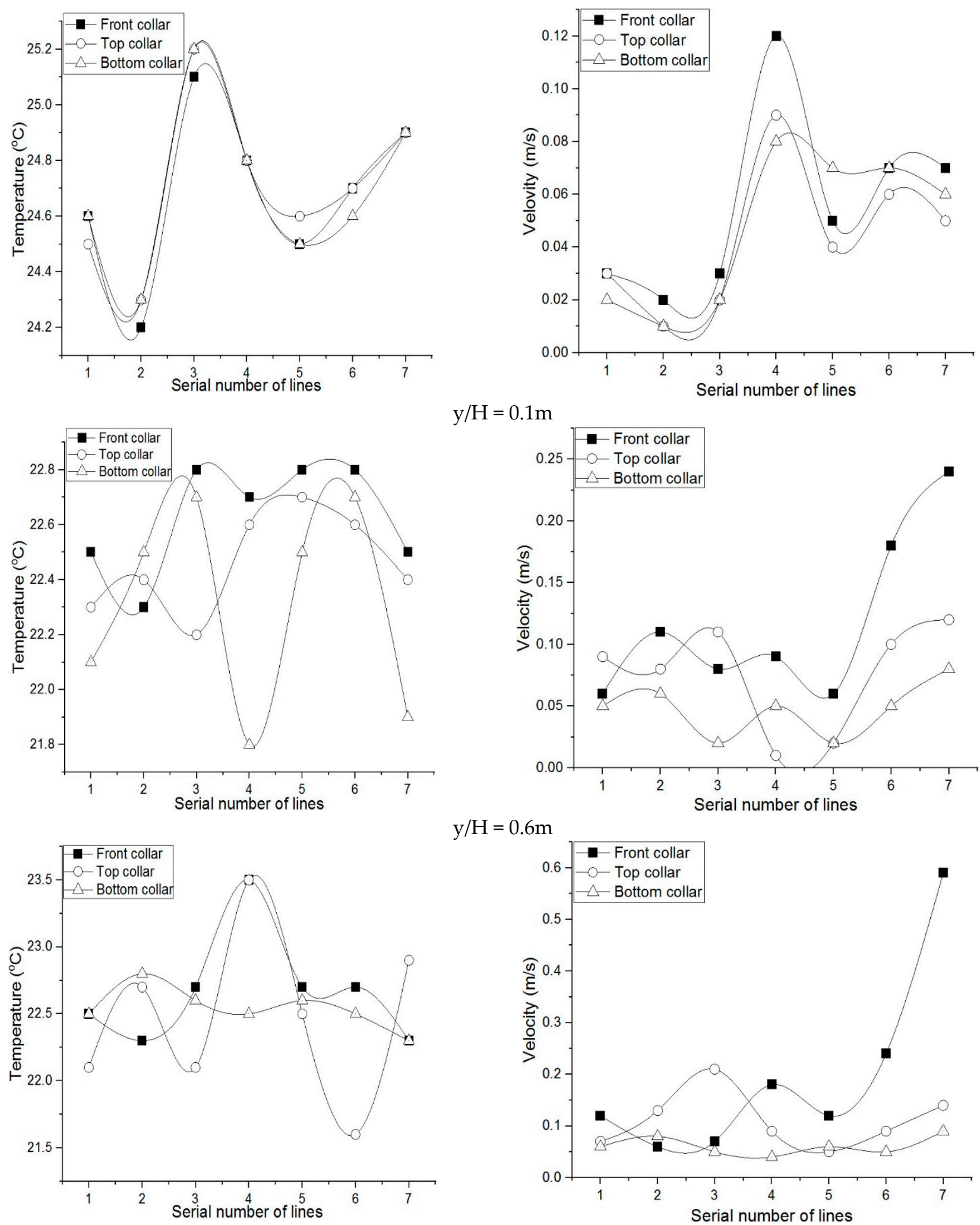

$\mathrm{y} / \mathrm{H}=0.6 \mathrm{~m}$

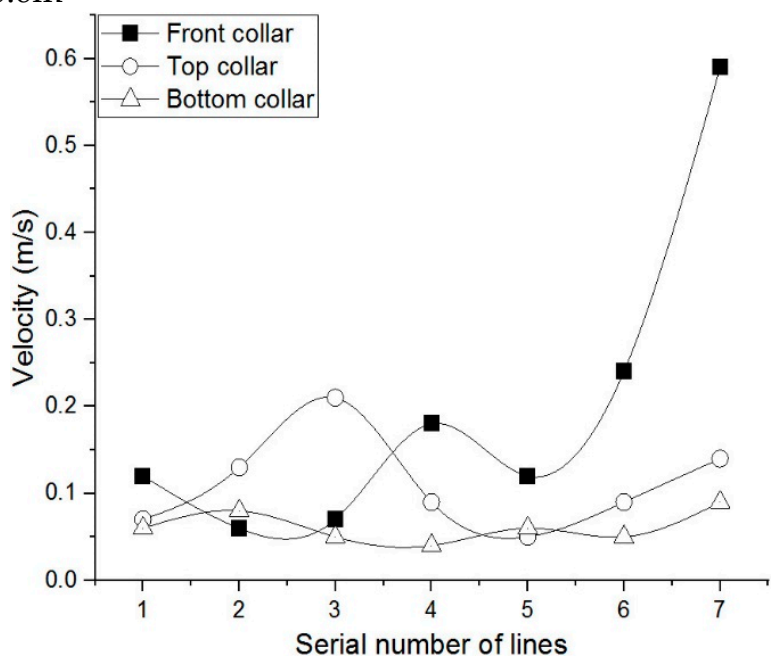

$\mathrm{y} / \mathrm{H}=1.1 \mathrm{~m}$

Figure 7. Cont. 

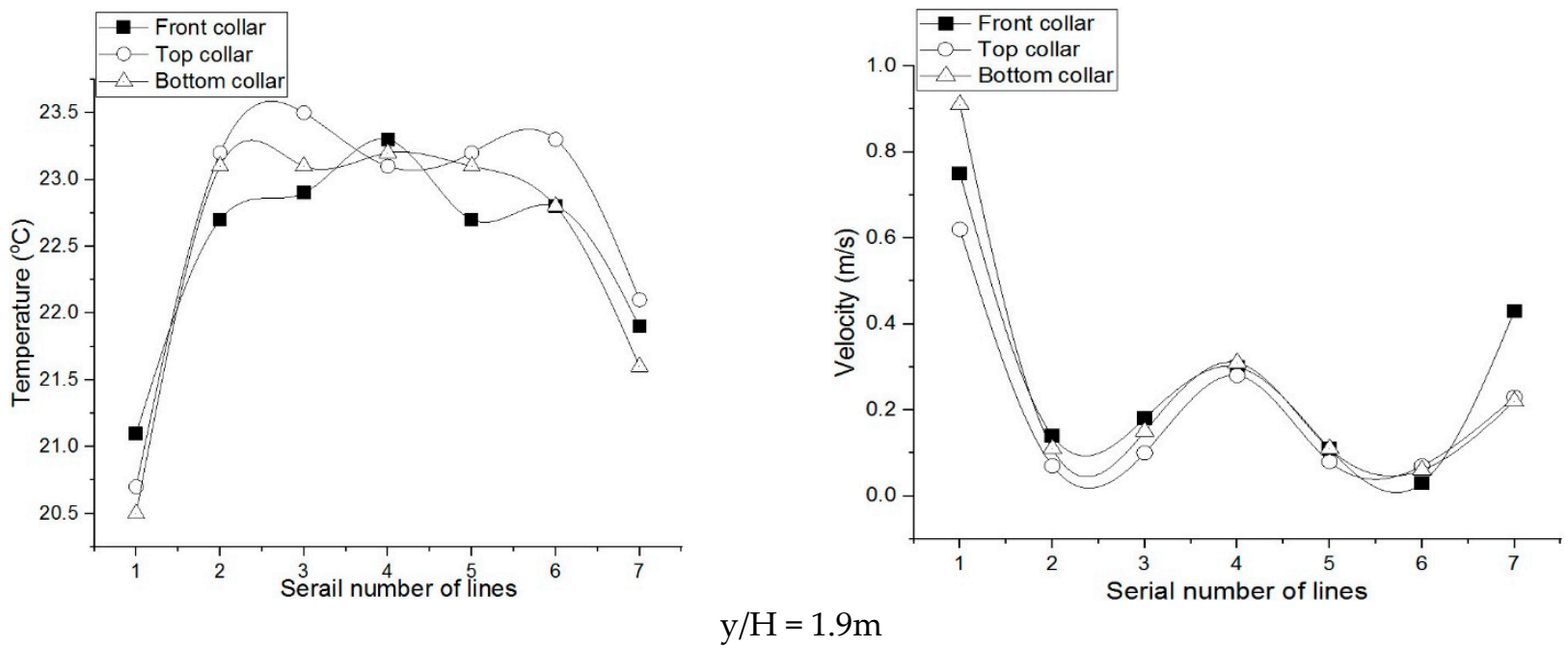

Figure 7. Comparison of temperature and velocity values for different orientations of the flexible duct collar along measured locations at heights $0.1,0.6,1.1$ and $1.9 \mathrm{~m}$ from the floor.

\subsubsection{Effect on Temperature Field Distribution}

Figure $8 \mathrm{a}, \mathrm{b}$ shows the temperature field distribution at different positions (L1 to L7) at heights of 0.6 and $1.1 \mathrm{~m}$, respectively. The higher temperature values of $22.8^{\circ} \mathrm{C}$ to $24.8^{\circ} \mathrm{C}$ were recorded at all the locations for the jet slot diffuser, demonstrating the unsuitability of these types of diffusers in VRF integrated stratum ventilation systems. Its poor performance may have been due to the horizontal installation on the sidewall. The lowest temperature by these ASTDs was observed with the perforated type diffuser at location L1 at the measured heights. After exiting the supply inlet in the perforated diffuser, the air dipped down deeply into the room with very low entrainment and momentum. It could be a reason for the lowest temperature values of about $21.5^{\circ} \mathrm{C}$ and $21.28^{\circ} \mathrm{C}$ observed at the measuring heights at location L1. However, at all other locations and on both the measuring heights, temperature ranges of about $21.5-23.4^{\circ} \mathrm{C}, 21.2-23.3^{\circ} \mathrm{C}$ and $22.3-23.5^{\circ} \mathrm{C}$ were noted for the drum louver diffuser, double deflection grille and bar grille diffuser, respectively. Moreover, the bar grille diffuser showed uniform temperature distribution at all locations. The value fluctuated at about $22.5^{\circ} \mathrm{C}$, except location $\mathrm{L} 4$ at height $1.1 \mathrm{~m}$, where the maximum deviation was $1^{\circ} \mathrm{C}$ from the mean.

\subsubsection{Effect on Velocity Distribution}

The higher velocity value of $>0.1 \mathrm{~m} / \mathrm{s}$ was seen with a double deflection grille at $0.6 \mathrm{~m}$ and $1.1 \mathrm{~m}$ heights at location L1, as shown in Figure 9. All other ASTDs showed lower values at this location, especially in the case with the drum louver diffuser, where the velocity at height $1.1 \mathrm{~m}$ at location $\mathrm{L} 6$ was measured highest, about $0.7 \mathrm{~m} / \mathrm{s}$. Due to the low velocity values at all the locations and poor airflow distributions by the perforated and jet slot diffusers, both were found unsuitable for VRF-SV hybrid system applications. However, for other terminals, the effects of ASTDs on the VRF-SV system performance in terms of velocity distribution was found to be less influential. It was similar for all measuring locations except L6 and L7, where the deviations recorded were $0.03-0.5 \mathrm{~m} / \mathrm{s}$ and $0.01-0.46 \mathrm{~m} / \mathrm{s}$, respectively. Therefore, any of the remaining three diffuser types can be installed with the VRF-SV hybrid system to obtain more uniform airflow distribution. 


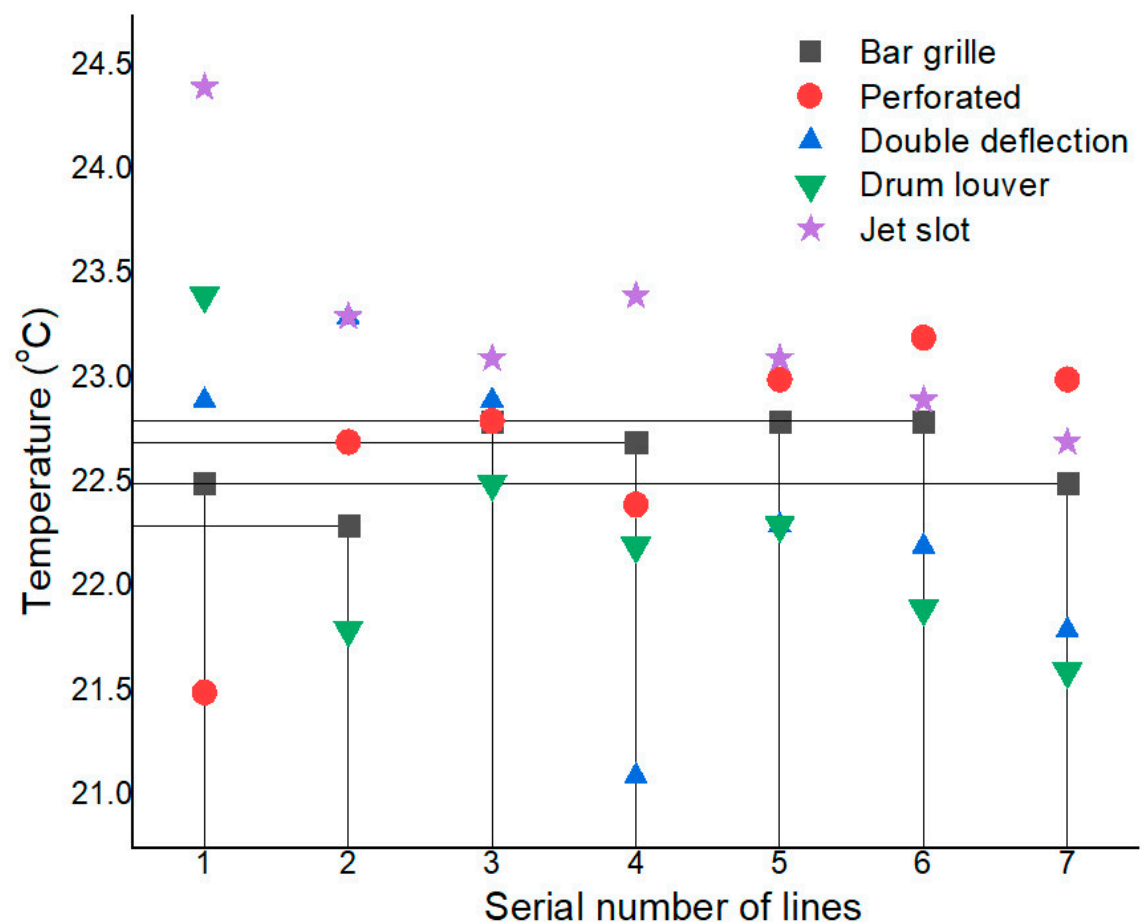

(a)

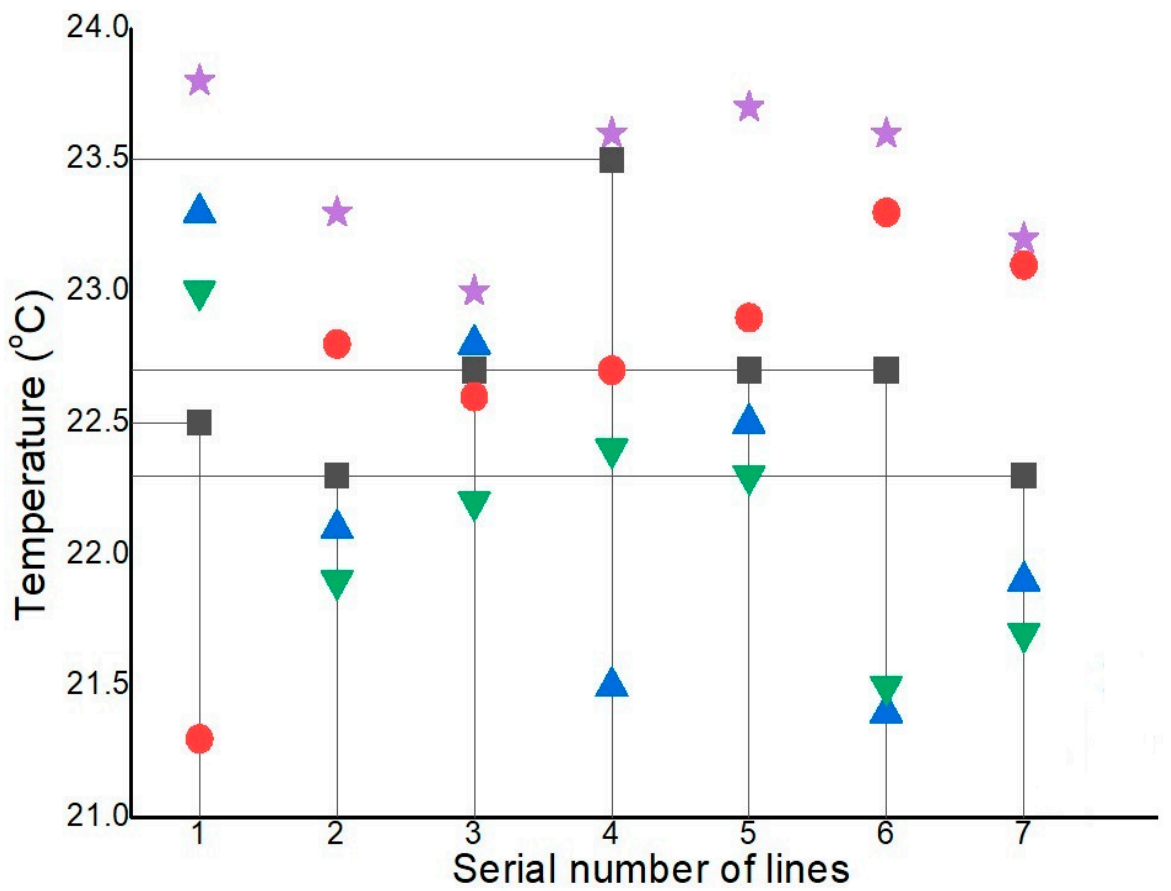

(b)

Figure 8. Temperature distribution at Positions L1 to L7 at the height of (a) $0.6 \mathrm{~m}$ and (b) $1.1 \mathrm{~m}$ from the floor. 


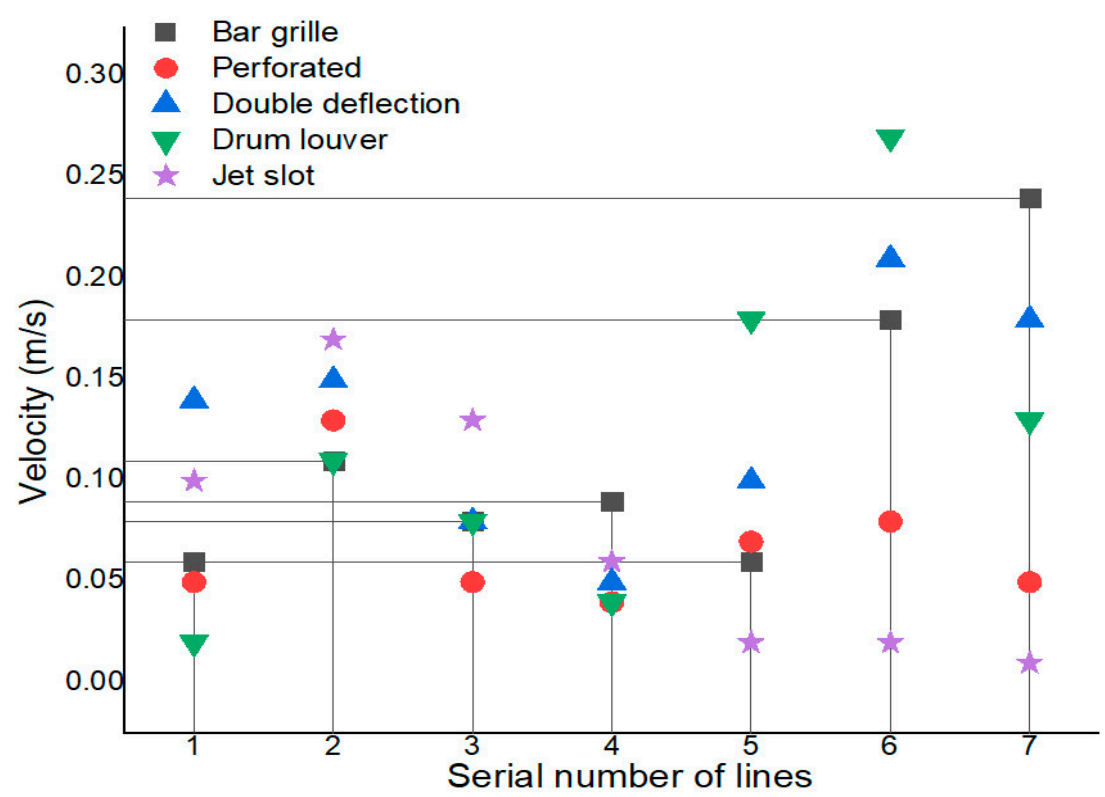

(a)

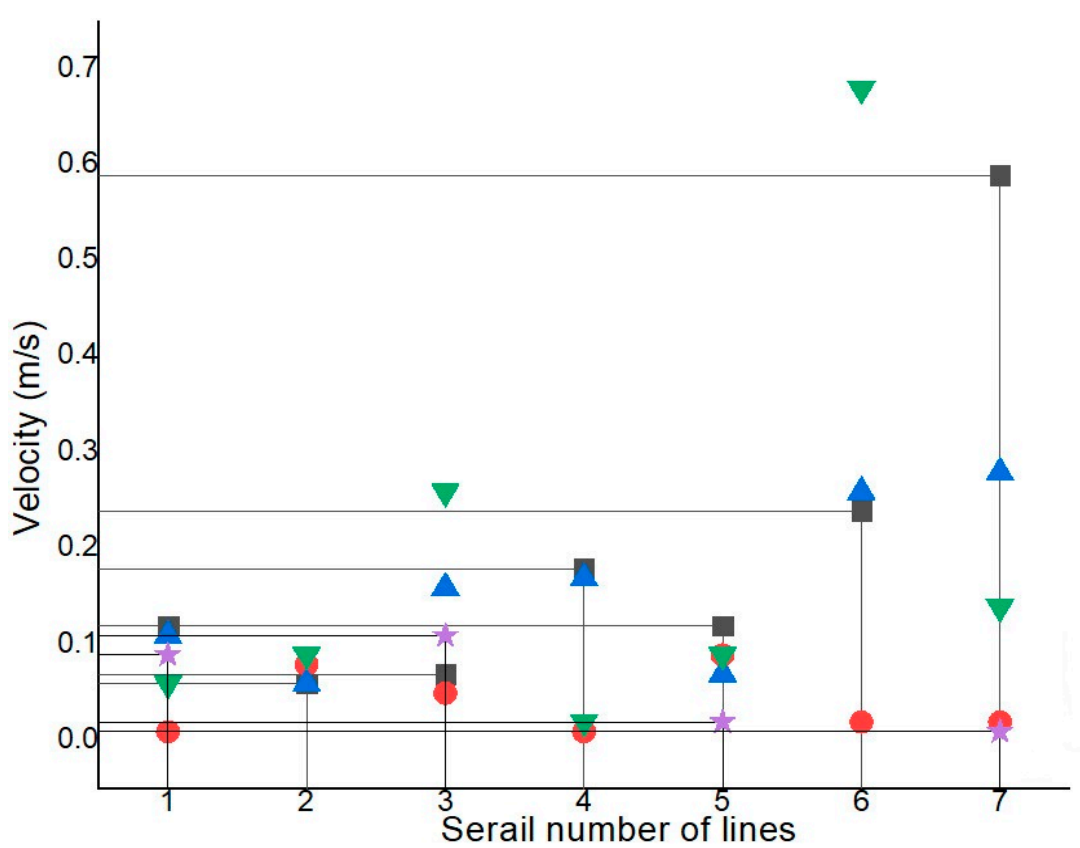

(b)

Figure 9. Velocity distribution at Positions L1 to L7 at the height of (a) $0.6 \mathrm{~m}$ and (b) $1.1 \mathrm{~m}$ from the floor.

\subsubsection{Effect on Airflow Throw}

To further explore the effects of ASTDs, Figure 10 presents the airflow throw analyses for all the studied terminals. The measuring height selected for diffusers' throw analysis was $1.9 \mathrm{~m}$ from the floor. It was at the mid-height of the ASTD. The airflow through different diffusers was measured at five different locations. These locations were in front of the supply terminals in the throw direction. The skewedness in the case with the jet slot diffuser at a $2 \mathrm{~m}$ distance from the diffuser face was due to the uneven airflow from the jet slot diffuser. Air velocity at the diffuser center was low $(<0.1 \mathrm{~m} / \mathrm{s})$ and it was higher at both ends ( $>0.1 \mathrm{~m} / \mathrm{s})$. For double deflection grille, bar grille and drum louvre diffuser, the jet of air decayed proportionally to the distance from the diffuser. Among them, the airflow 
velocity of the bar grille case decayed most rapidly at a distance of about $3 \mathrm{~m}$ from the grille face, where the jet of the air almost vanished. However, the slowest decay was observed with the double deflection grille, in which the jet of air lasted for $5 \mathrm{~m}$ distance from the diffuser face. Furthermore, the air jet through the drum louver diffuser also reached the same distance achieved by the double deflection grille with even low face velocity than the former. Therefore, these diffusers, i.e., bar grille, perforated diffuser, double deflection grille and drum louver diffuser, were further investigated for smoke test analyses.

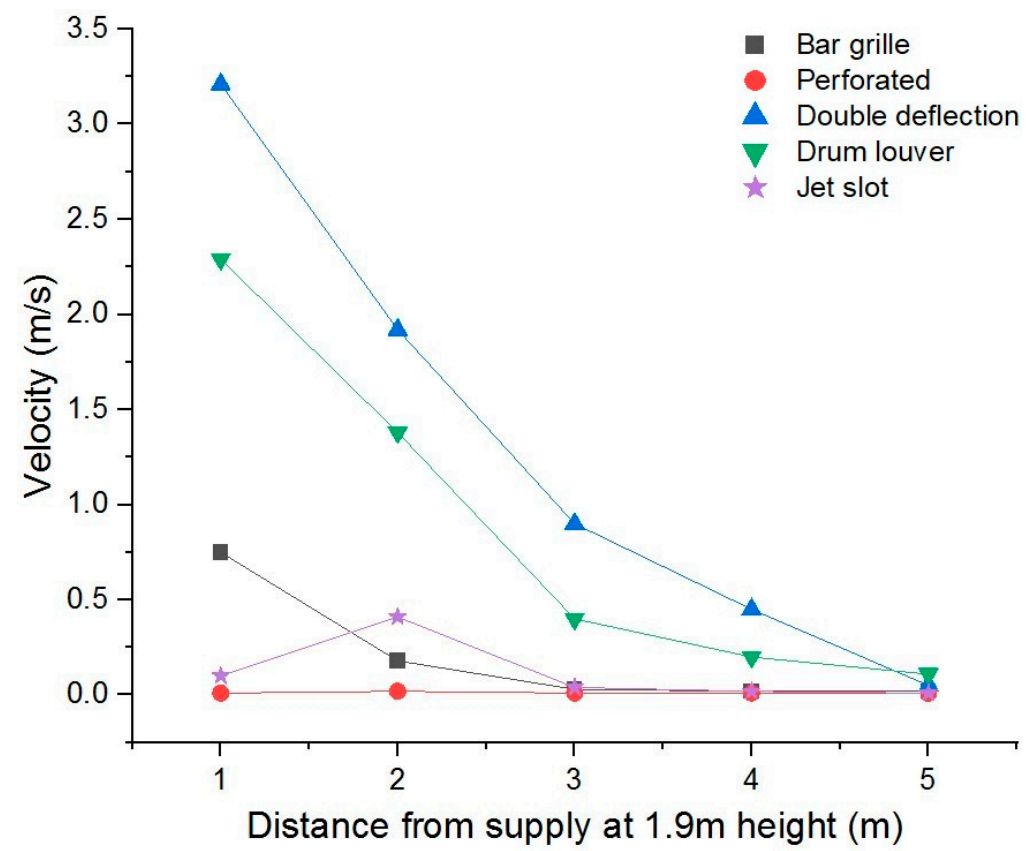

Figure 10. Comparison of airflow throw from different diffusers.

\subsubsection{Effect on EDT and ADPI}

Equation (1) determined the EDT for VRF-SV hybrid system using selected ASTDs, at different heights of $0.1,0.6,1.1$ and $1.9 \mathrm{~m}$ from the floor. Limited by the paper length, only the values at 0.6 and $1.1 \mathrm{~m}$ heights were presented, as seen in Figure 11 . All the EDT values of the bar grille case were found within the acceptable range of $-1.2 \mathrm{~K}<\theta_{\text {edt }}<1.2 \mathrm{~K}$, except one value $(1.3 \mathrm{~K})$ at line location 4 and height $1.1 \mathrm{~m}$ found out of the acceptable range. Most of the EDT values for the four diffusers (bar grille, perforated, double deflection and drum louver) were found to be under the acceptable limits. However, the EDT values of the jet slot diffuser case were all found to be out of the specified limits. This may have been due to improper distribution of temperature and velocity by this type of diffuser. Based on the calculated values, the ADPI for all the ASTDs were determined, as presented in Table 5. In order to properly distribute the temperature and airflow velocity and to comply with the ASHRAE thermal comfort standards, the ADPI value must not be lower than $80 \%$ in summer conditions [43]. The ADPI value obtained for the case with bar grille diffuser satisfied this standard. Thus, this type of diffuser can be recommended to be installed with VRF-SV hybrid systems in buildings. 


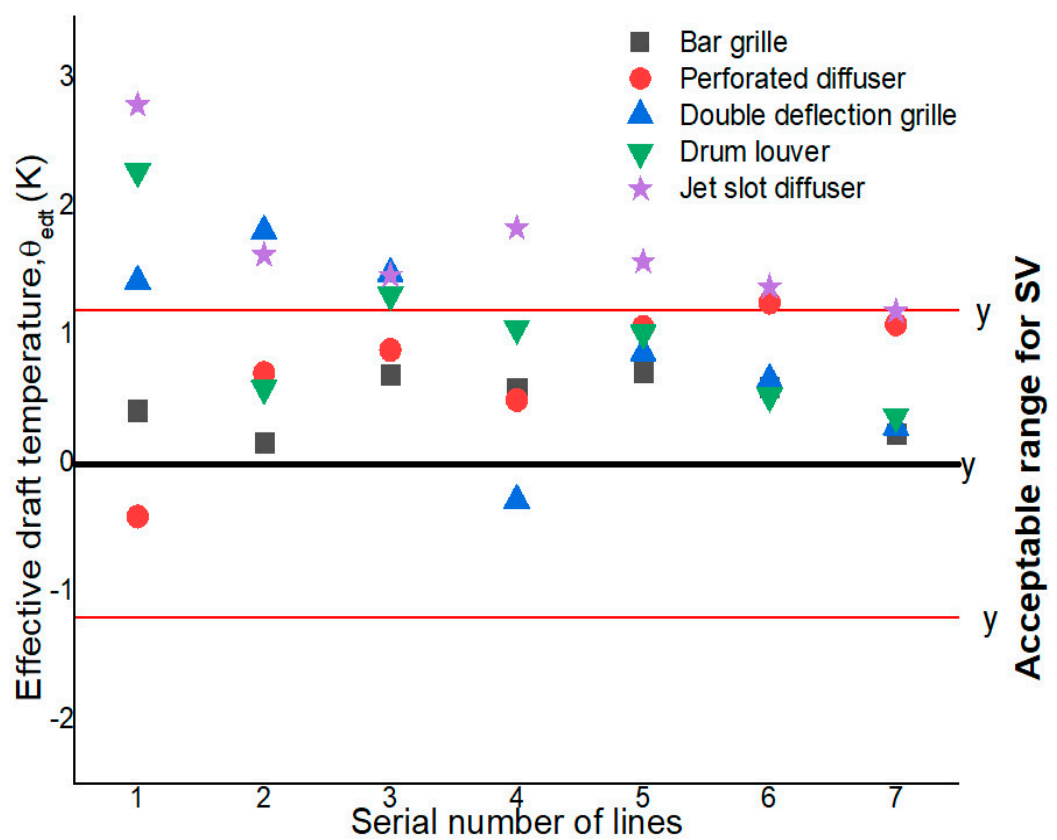

(a)

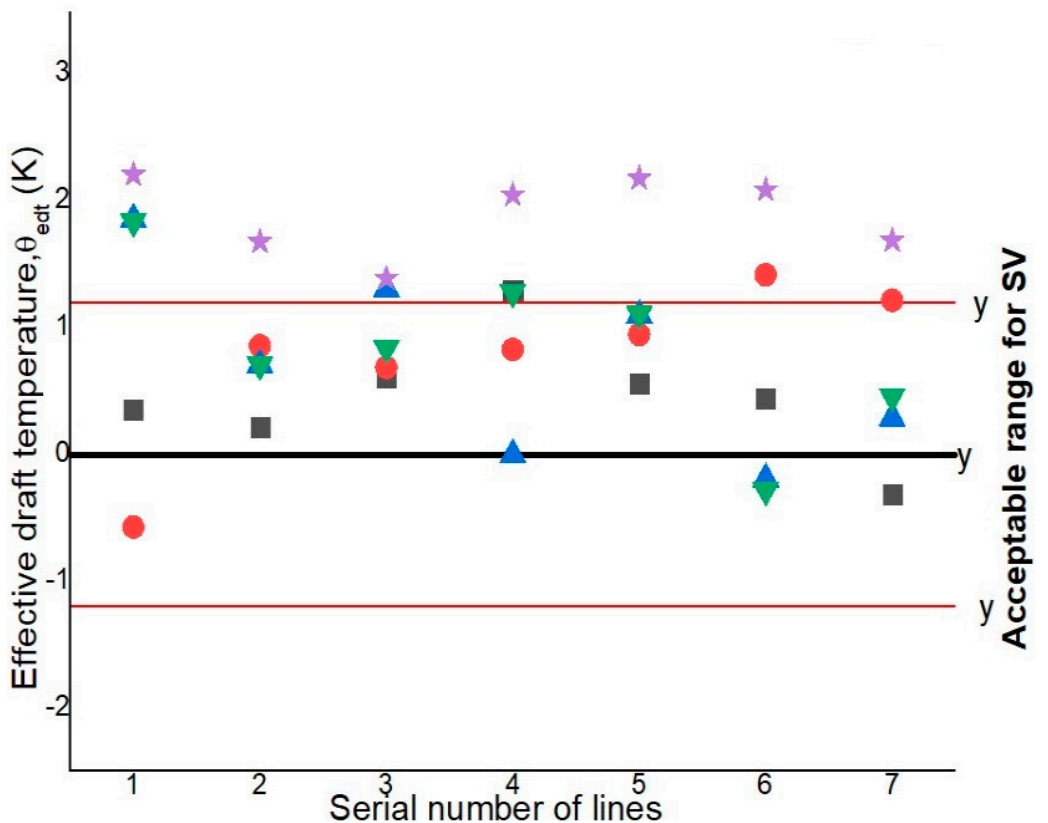

(b)

Figure 11. Effective draft temperature, $\theta_{\text {edt }}$ at the height (a) $0.6 \mathrm{~m}$ and (b) $1.1 \mathrm{~m}$.

\subsubsection{Effect on Airflow Pattern (Smoke Test)}

Airflow visualization testing is more commonly known as smoke testing. The smoke tests rely on visual smoke generated in the cleanroom or laboratory environment. The smoke tests visualize the supplied air in the room through ASTDs. Figure 12 shows the visuals of different flow patterns through bar grille, double deflection grille, perforated and drum louver diffusers. The longer airflow throw could be seen in the case with double deflection grille, while flow in the perforated diffuser case was short and highly diffusive. Weak entrainment was also observed with this type of diffuser. A medium but strong air entrainment and momentum was observed with the bar grille diffuser case. 

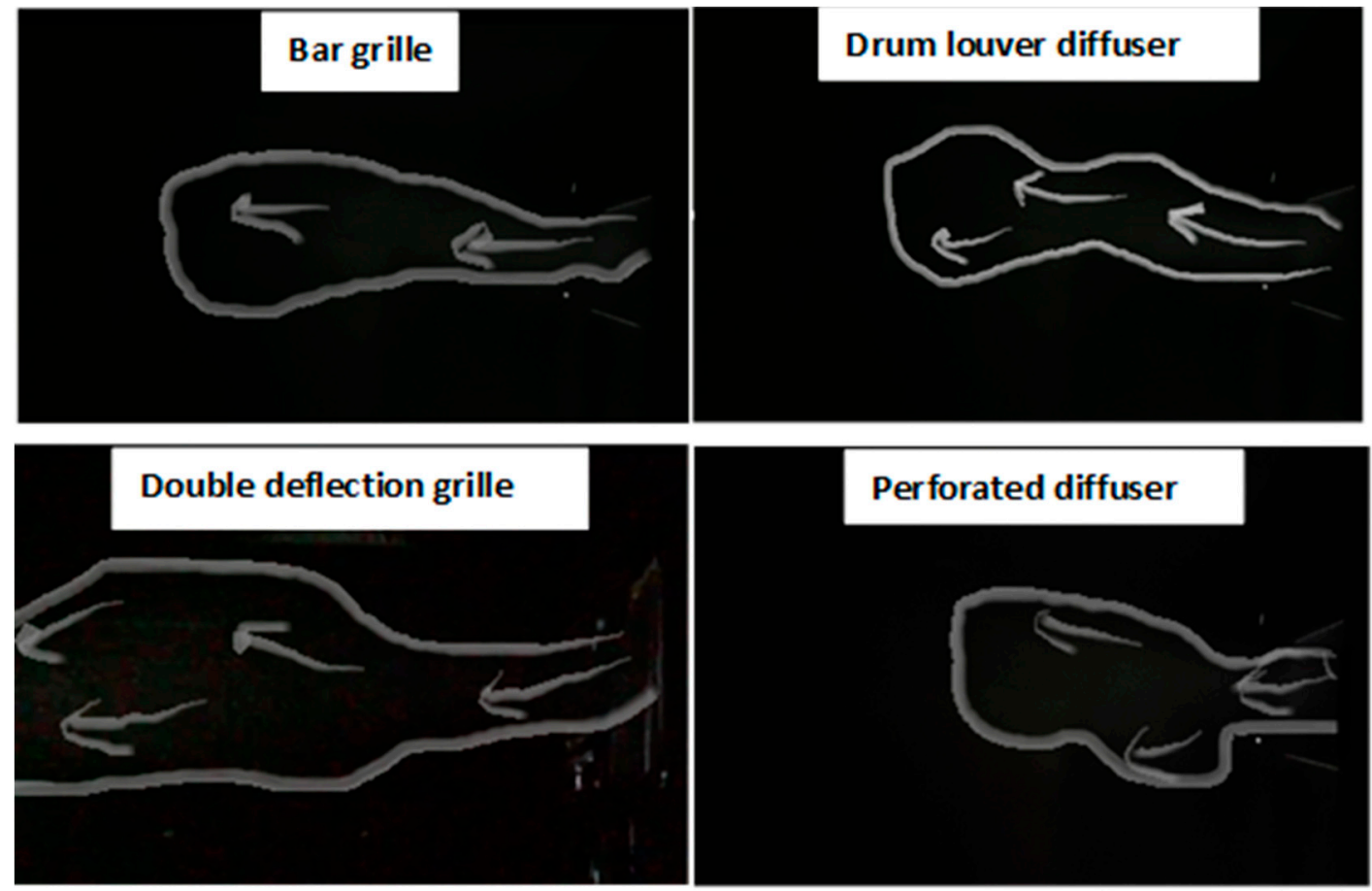

Figure 12. Airflow pattern at $0^{\circ}$ blade angle through different ASTDs (smoke visualization).

\subsubsection{Effect on Thermal Comfort (Subjective Test)}

Figure 13 shows the responses of the subjects surveyed under the meeting room environment to investigate the effects of ASTDs on human thermal sensation and comfort. It was noted that all the ASTDs provided different levels of thermal comfort to the occupants, which showed a significant effect of ASTDs on human thermal comfort. The cases with bar grille and double deflection grille performed better than perforated and drum louver diffusers. For the bar grille case, $70 \%$ of the subjects graded the thermal sensation as slightly cool, whereas $60 \%$ rated the thermal comfort as comfortable. In the case with a perforated diffuser, $20 \%$ of the subjects rated the thermal sensation and comfort as slightly warm and uncomfortable. The low throw by this diffuser prevented the subjects sitting far from the supply from feeling the cooling effects.

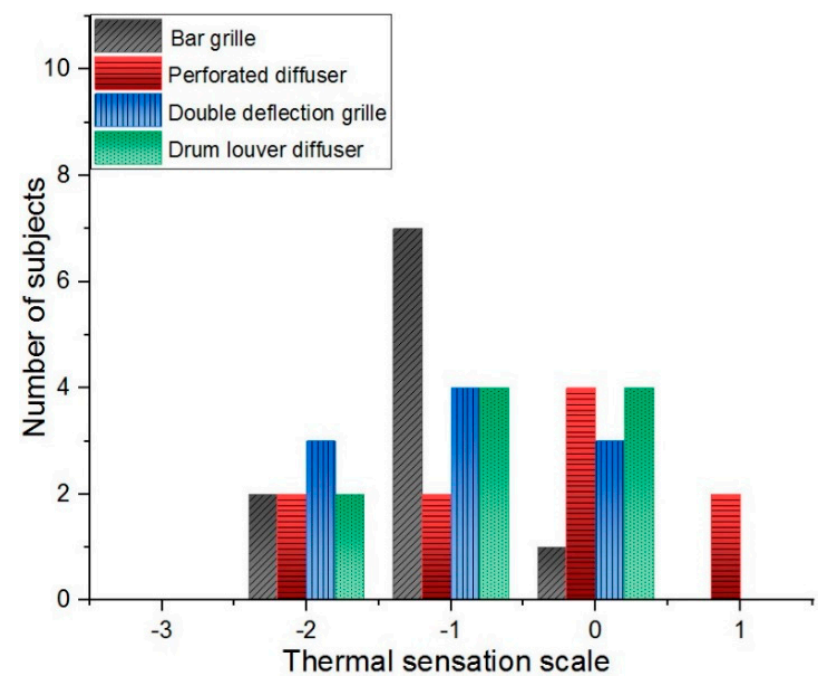

(a)

Figure 13. Cont. 


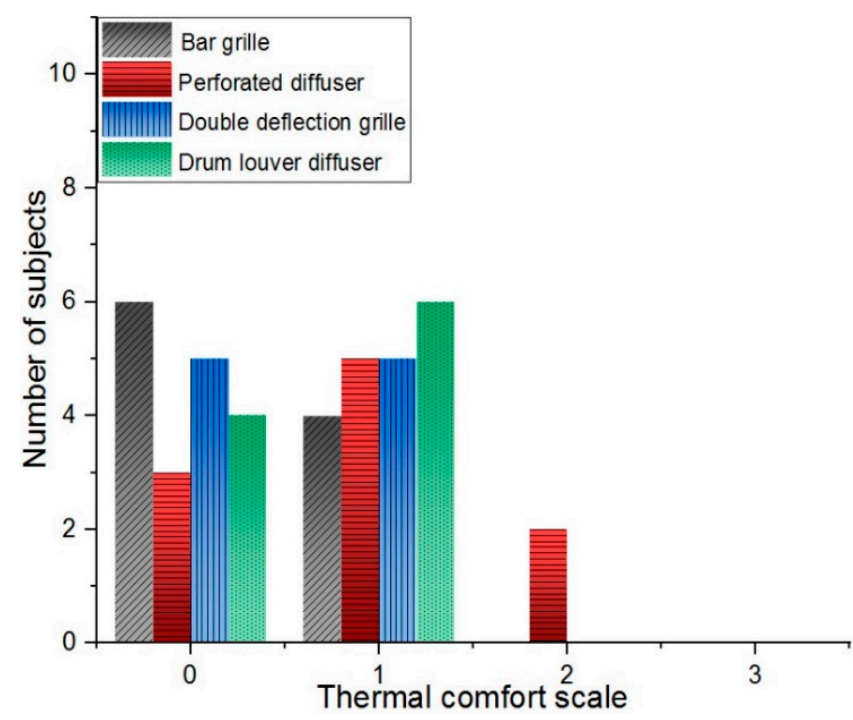

(b)

Figure 13. Thermal sensation and comfort survey (Human subjects test) (a) TSV and (b) TCV.

\section{Conclusions}

In this study, the air distribution and thermal comfort performance of a VRF-SV hybrid system with five types of ASTD were successfully investigated through laboratory experiments. Under the air distribution aspect, airflow distribution, airflow pattern, EDT and ADPI were evaluated. The thermal comfort performance delivered by each ASTD was measured quantitatively by subjective assessments. Before the actual experimental measurements, the uniformity of the axial airflow jet (that is, discharge from different ASTDs and the effects of top, side and bottom collar orientations on it) were briefly investigated. It was concluded that the plenum collar orientation had a more significant impact on airflow velocity distribution than the temperature distribution. The higher outflow was observed when the supply air entry was in line with the flow direction with collar attachment on the front face of the plenum box (Front collar orientation).

Based on the detailed experimental results, we concluded that:

- Uniform temperature distribution at all locations was created with bar grille diffuser, while the temperature value fluctuated at about $22.5^{\circ} \mathrm{C}$.

- Influential or distinct performance in terms of velocity distribution was not observed with any of the studied diffuser types.

- The ADPI for the bar grille was calculated as $92.8 \%$. The ADPI values for all other ASTD types fell below the minimum required range.

- The thermal sensation and comfort survey suggested that the bar grille provided a better thermal environment than all other diffuser types. For the bar grille case, 70\% of the subjects graded the thermal sensation as slightly cool, whereas $60 \%$ rated the thermal comfort as comfortable.

- The airflow visualization using smoke tests showed a longer airflow throw in the case with double deflection grille, while the flow in the perforated diffuser case was shorter and highly diffusive. The jet entrainment with the bar grille case was uniform and moderate.

Above all, the VRF-SV system installed with the bar grille as ASTD provided better thermal comfort, uniform temperature and velocity distribution within the space. Thus, the bar grille can be recommended to be installed with VRF-SV hybrid systems in building applications. The results of this study could also be used as an important guide for optimization of the air distribution performance of the VRF-SV hybrid system in buildings. 
Author Contributions: Conceptualization, Y.H.Y. and U.A.R.; methodology, Y.H.Y. and U.A.R.; software, U.A.R.; validation, U.A.R. and N.L; formal analysis, U.A.R. and A.H.R.; investigation, U.A.R.; resources, Y.H.Y.; data curation, U.A.R. and N.L.; writing-original draft preparation, U.A.R.; writing-review and editing, Y.H.Y. and A.H.R.; visualization, N.L.; supervision, Y.H.Y.; project administration, Y.H.Y.; funding acquisition, Y.H.Y. All authors have read and agreed to the published version of the manuscript.

Funding: This research is funded by University of Malaya Partnership Grant RK005-2020, GPF Grant GPF004A-2018 and IIRG Grant IIRG014-2019A. This research is also funded by the Deanship of Scientific Research at Jouf University under grant No (DSR-2021-02-03108).

Institutional Review Board Statement: Not applicable.

Informed Consent Statement: Not applicable.

Data Availability Statement: Not applicable.

Acknowledgments: The authors would like to acknowledge the funding supports of University of Malaya and Jouf University. Thanks are extended to Pakistan Government for the full scholarship provided to the first co-author, U.A. Rajput, for conducting PhD research work in the HVAC\&R Lab at the Department of Mechanical Engineering, University of Malaya. In addition, special thanks are extended to Prudentaire Engineering Sdn Bhd and Daikin R\&D Sdn Bhd for their contributions in the laboratory testing and simulation work conducted in this project.

Conflicts of Interest: On behalf of all authors, the corresponding author states that there is no conflict of interest.

\section{Nomenclature}

\section{Symbols \& Units}

${ }^{\circ} \mathrm{C} \quad$ Degree Celsius

K Kelvin

W Weight

$\mathrm{H} \quad$ Height

L $\quad$ Length $(\mathrm{m})$

$\mathrm{m} \quad$ Meter

$\mathrm{m} / \mathrm{s} \quad$ Meter per second

$\mathrm{m}^{3} / \mathrm{s} \quad$ Cubic meter per second

$\mathrm{s} \quad$ Second

T Temperature

W Watt

$N \quad$ Points measured in occupied space $\mathrm{OA}$

$\mathrm{kg} / \mathrm{m}^{2} \quad$ Kilogram per square meter

$x \quad$ Measured value

$\mathrm{x}, \mathrm{y}, \mathrm{z} \quad$ Cartesian coordinates (m)

$\bar{x} \quad$ Average measured value

$\mathrm{W} / \mathrm{m}^{2} \cdot \mathrm{K}$ Watt per square meter per kelvin

$\theta \quad$ Temperature difference

\section{Subscripts}

c At room level

max Maximum

\section{Abbreviations}

ACMV Air conditioning and mechanical ventilation

ADPI Air diffusion performance index

ASTDs Air supply terminal devices

ASTD Air supply terminal device

BMI Body mass index

BSA Body surface area

DOAS Dedicated outdoor air system

DV Displacement ventilation

EDT Effective draft temperature

IAQ Indoor air quality

MV Mixing ventilation

Outdoor air

SV Stratum ventilation

TC Thermal comfort

TCV Thermal comfort vote

TSV Thermal sensation vote

VAV Variable air volume

VRF Variable refrigerant flow

min Minimum

$x \quad$ At any local point 
Appendix A. Questionnaire for Filed Survey

\section{Anthropometric Data:}

Gender:

Age:

Height:

Weight:

Clothing Type:

Thermal sensation vote:

1) Please tick $(\sqrt{ })$ one option to represent your temperature sense with the indoor environment.

Cold<smiles>O=C(O)C1CCC1</smiles><smiles>C1CCC1</smiles>
Slightly cool $\square$ Neutral
$\square$ Slightly warm
$\square$ Warm
Hot

Thermal comfort vote:

2) Please tick $(\sqrt{ })$ one option to represent your thermal comfort level with the indoor environment. 


\section{Appendix B}

Table A1. Bias uncertainty for the air velocity and temperature measurement.

\begin{tabular}{|c|c|c|c|c|c|c|c|c|c|c|c|c|c|c|c|c|c|}
\hline & & \multicolumn{6}{|c|}{ Velocity (m/s) } & \multirow{2}{*}{\multicolumn{2}{|c|}{$\begin{array}{c}\text { Bias } \\
\text { Uncertainty } \\
(\%)\end{array}$}} & \multicolumn{6}{|c|}{ Temperature $\left({ }^{\circ} \mathrm{C}\right)$} & \multirow{2}{*}{\multicolumn{2}{|c|}{$\begin{array}{c}\text { Bias } \\
\text { Uncertainty } \\
(\%)\end{array}$}} \\
\hline & & \multicolumn{2}{|c|}{ Min. } & \multicolumn{2}{|c|}{ Max. } & \multicolumn{2}{|c|}{ Avg. } & & & \multicolumn{2}{|c|}{ Min. } & \multicolumn{2}{|c|}{ Max. } & \multicolumn{2}{|c|}{ Avg. } & & \\
\hline & & 0.6 & 1.1 & 0.6 & 1.1 & 0.6 & 1.1 & 0.6 & 1.1 & 0.6 & 1.1 & 0.6 & 1.1 & 0.6 & 1.1 & 0.6 & 1.1 \\
\hline \multirow{7}{*}{ Bar Grille } & 1 & 0.00 & 0.07 & 0.11 & 0.21 & 0.06 & 0.12 & 91.67 & 58.33 & 22.4 & 22.5 & 22.6 & 22.5 & 22.5 & 22.5 & 0.44 & 0 \\
\hline & 2 & 0.04 & 0.06 & 0.22 & 0.19 & 0.11 & 0.06 & 81.81 & 108.33 & 22.2 & 22.3 & 22.4 & 22.3 & 22.3 & 22.3 & 0.44 & 0 \\
\hline & 3 & 0.02 & 0.00 & 0.08 & 0.07 & 0.08 & 0.07 & 37.5 & 50 & 22.7 & 22.7 & 22.8 & 22.7 & 22.8 & 22.7 & 0.22 & 0 \\
\hline & 4 & 0.02 & 0.09 & 0.09 & 0.26 & 0.09 & 0.18 & 38.89 & 47.22 & 22.6 & 23.1 & 22.7 & 23.5 & 22.7 & 23.5 & 0.22 & 0.85 \\
\hline & 5 & 0.06 & 0.12 & 0.18 & 0.24 & 0.06 & 0.12 & 100 & 50 & 22.7 & 22.6 & 22.8 & 22.7 & 22.8 & 22.7 & 0.43 & 0.22 \\
\hline & 6 & 0.09 & 0.03 & 0.18 & 0.45 & 0.18 & 0.24 & 25 & 87.5 & 22.7 & 22.7 & 22.9 & 22.7 & 22.8 & 22.7 & 0.43 & 0 \\
\hline & 7 & 0.24 & 0.49 & 0.31 & 0.59 & 0.24 & 0.59 & 14.58 & 8.47 & 22.4 & 22.0 & 22.6 & 22.5 & 22.5 & 22.3 & 0.44 & 1.12 \\
\hline \multirow{7}{*}{$\begin{array}{l}\text { Double } \\
\text { deflection } \\
\text { Grille }\end{array}$} & 1 & 0.02 & 0.00 & 0.14 & 0.21 & 0.14 & 0.11 & 42.85 & 95.45 & 22.9 & 23.3 & 23.2 & 23.4 & 22.9 & 23.3 & 0.65 & 0.21 \\
\hline & 2 & 0.11 & 0.00 & 0.18 & 0.06 & 0.15 & 0.06 & 23.33 & 50 & 21.3 & 22.1 & 24.8 & 22.5 & 23.3 & 22.1 & 7.51 & 0.90 \\
\hline & 3 & 0.06 & 0.01 & 0.12 & 0.19 & 0.08 & 0.16 & 37.5 & 56.25 & 22.9 & 22.8 & 23.0 & 22.8 & 22.9 & 22.8 & 0.21 & 0 \\
\hline & 4 & 0.01 & 0.05 & 0.05 & 0.18 & 0.05 & 0.17 & 40 & 38.23 & 21.1 & 21.5 & 21.3 & 21.8 & 21.1 & 21.5 & 0.47 & 0.69 \\
\hline & 5 & 0.10 & 0.02 & 0.18 & 0.07 & 0.1 & 0.07 & 40 & 35.71 & 22.0 & 22.5 & 22.6 & 22.6 & 22.3 & 22.5 & 1.34 & 0.22 \\
\hline & 6 & 0.10 & 0.16 & 0.21 & 0.26 & 0.21 & 0.26 & 26.19 & 9.61 & 22.0 & 21.4 & 22.3 & 21.8 & 22.2 & 21.4 & 0.67 & 0.93 \\
\hline & 7 & 0.02 & 0.15 & 0.21 & 0.30 & 0.18 & 0.28 & 52.78 & 26.78 & 21.8 & 21.9 & 21.9 & 21.9 & 21.8 & 21.9 & 0.22 & 0 \\
\hline \multirow{7}{*}{$\begin{array}{l}\text { Perforated } \\
\text { Diffuser }\end{array}$} & 1 & 0.04 & 0.00 & 0.09 & 0.01 & 0.05 & 0.01 & 50 & 50 & 19.9 & 21.0 & 23.1 & 21.6 & 21.5 & 21.3 & 7.44 & 1.41 \\
\hline & 2 & 0.13 & 0.08 & 0.16 & 0.13 & 0.13 & 0.08 & 11.53 & 31.25 & 22.7 & 22.7 & 22.8 & 22.8 & 22.7 & 22.8 & 0.22 & 0.22 \\
\hline & 3 & 0.01 & 0.01 & 0.12 & 0.12 & 0.05 & 0.05 & 110 & 110 & 22.6 & 22.6 & 22.8 & 22.8 & 22.8 & 22.6 & 0.43 & 0.44 \\
\hline & 4 & 0.01 & 0.00 & 0.09 & 0.03 & 0.04 & 0.01 & 100 & 150 & 22.3 & 22.5 & 22.5 & 22.9 & 22.4 & 22.7 & 0.44 & 0.88 \\
\hline & 5 & 0.07 & 0.06 & 0.15 & 0.12 & 0.07 & 0.09 & 57.14 & 33.33 & 22.9 & 22.9 & 23.0 & 23.0 & 23.0 & 22.9 & 0.21 & 0.21 \\
\hline & 6 & 0.06 & 0.01 & 0.08 & 0.03 & 0.08 & 0.02 & 12.5 & 50 & 23.2 & 23.2 & 23.2 & 23.3 & 23.2 & 23.3 & 0 & 0.21 \\
\hline & 7 & 0.00 & 0.00 & 0.05 & 0.02 & 0.05 & 0.02 & 50 & 50 & 23.0 & 23.1 & 23.1 & 23.2 & 23.0 & 23.1 & 0.21 & 0.21 \\
\hline \multirow{7}{*}{$\begin{array}{l}\text { Drum } \\
\text { louver } \\
\text { Diffuser }\end{array}$} & 1 & 0.00 & 0.03 & 0.06 & 0.10 & 0.02 & 0.06 & 150 & 58.33 & 23.2 & 22.8 & 23.6 & 23.0 & 23.4 & 23.0 & 0.85 & 0.43 \\
\hline & 2 & 0.11 & 0.04 & 0.20 & 0.15 & 0.11 & 0.09 & 40.90 & 61.11 & 21.6 & 21.9 & 21.9 & 22.1 & 21.8 & 21.9 & 0.68 & 0.45 \\
\hline & 3 & 0.08 & 0.21 & 0.13 & 0.30 & 0.08 & 0.26 & 31.25 & 17.31 & 22.2 & 21.9 & 22.5 & 22.5 & 22.5 & 22.2 & 0.66 & 1.35 \\
\hline & 4 & 0.00 & 0.00 & 0.12 & 0.03 & 0.04 & 0.02 & 150 & 75 & 22.1 & 22.2 & 22.3 & 22.6 & 22.2 & 22.4 & 0.45 & 0.89 \\
\hline & 5 & 0.09 & 0.09 & 0.18 & 0.18 & 0.18 & 0.09 & 25 & 50 & 22.3 & 22.3 & 22.3 & 22.3 & 22.3 & 22.3 & 0 & 0 \\
\hline & 6 & 0.18 & 0.68 & 0.29 & 0.82 & 0.27 & 0.68 & 20.37 & 10.29 & 21.8 & 21.2 & 21.9 & 21.8 & 21.9 & 21.5 & 0.22 & 1.39 \\
\hline & 7 & 0.04 & 0.14 & 0.15 & 0.25 & 0.13 & 0.14 & 42.30 & 39.28 & 21.4 & 21.4 & 21.7 & 21.8 & 21.6 & 21.7 & 0.69 & 0.92 \\
\hline \multirow{7}{*}{$\begin{array}{l}\text { Jet slot } \\
\text { diffuser }\end{array}$} & 1 & 0.05 & 0.03 & 0.13 & 0.13 & 0.1 & 0.09 & 40 & 55.55 & 24.4 & 24.1 & 24.5 & 24.7 & 24.4 & 24.4 & 0.20 & 1.23 \\
\hline & 2 & 0.14 & 0.08 & 0.22 & 0.15 & 0.17 & 0.12 & 23.52 & 29.16 & 23.3 & 23.3 & 23.4 & 23.3 & 23.3 & 23.3 & 0.21 & 0 \\
\hline & 3 & 0.05 & 0.07 & 0.17 & 0.16 & 0.13 & 0.11 & 46.15 & 40.91 & 23.1 & 23.0 & 23.2 & 23.0 & 23.1 & 23.0 & 0.21 & 0 \\
\hline & 4 & 0.02 & 0.00 & 0.12 & 0.05 & 0.06 & 0.05 & 83.33 & 50 & 23.4 & 23.6 & 23.4 & 23.6 & 23.4 & 23.6 & 0 & 0 \\
\hline & 5 & 0.01 & 0.00 & 0.03 & 0.04 & 0.02 & 0.02 & 50 & 100 & 23.0 & 23.6 & 23.2 & 23.7 & 23.1 & 23.7 & 0.43 & 0.21 \\
\hline & 6 & 0.02 & 0.00 & 0.02 & 0.02 & 0.02 & 0.01 & 0 & 100 & 22.7 & 23.5 & 23.1 & 23.8 & 22.9 & 23.6 & 0.87 & 0.63 \\
\hline & 7 & 0.01 & 0.00 & 0.01 & 0.03 & 0.01 & 0.01 & 0 & 150 & 22.5 & 22.9 & 22.9 & 23.5 & 22.7 & 23.2 & 0.88 & 1.29 \\
\hline
\end{tabular}

\section{References}

1. Baglivo, C. Dynamic Evaluation of the Effects of Climate Change on the Energy Renovation of a School in a Mediterranean Climate. Sustainability 2021, 13, 6375. [CrossRef]

2. Ejaz, A.; Jamil, F.; Ali, H.M. A novel thermal regulation of photovoltaic panels through phase change materials with metallic foam-based system and a concise comparison: An experimental study. Sustain. Energy Technol. Assess. 2022, 49, 101726. [CrossRef]

3. Chen, H. Experimental and numerical investigations of a ventilation strategy-impinging jet ventilation for an office environment. Ph.D. Thesis, Linköping University, The Institute of Technology, Linköping, Switzerland, 2014. Linköping Studies in Science and Technology Dissertation No. 1606.

4. Department of Energy, US. An assessment of energy technologies and research oppertunities. In Quadrennial Technology Review; United States Department of Energy: Washington, DC, USA, 2015.

5. Saab, R.; Al Quabeh, H.; Hassan Ali, M.I. Variable refrigerant flow cooling assessment in humid environment using different refrigerants. J. Environ. Manag. 2018, 224, 243-251. [CrossRef]

6. Amoatey, P.; Omidvarborna, H.; Baawain, M.S.; Al-Mamun, A. Impact of building ventilation systems and habitual indoor incense burning on SARS-CoV-2 virus transmissions in Middle Eastern countries. Sci. Total Environ. 2020, 733, 139356. [CrossRef] 
7. Aynur, T.N.; Hwang, Y.; Radermacher, R. Integration of variable refrigerant flow and heat pump desiccant systems for the cooling season. Appl. Therm. Eng. 2010, 30, 917-927. [CrossRef]

8. Laughman, C.R.; Bortoff, S.A.; Qiao, H. Integrated Control of Multi-Zone Buildings with Ventilation and VRF Systems in Cooling Mode; Mitsubishi Electric Research Laboratories: Cambridge, MA, USA, 2018.

9. Wan, H.; Cao, T.; Hwang, Y.; Oh, S. A review of recent advancements of variable refrigerant flow air-conditioning systems. Appl. Therm. Eng. 2020, 169, 114893. [CrossRef]

10. Lin, Z.; Chow, T.T.; Tsang, C.F.; Fong, K.F.; Chan, L.S. Stratum ventilation-A potential solution to elevated indoor temperatures. Build. Environ. 2009, 44, 2256-2269. [CrossRef]

11. Lin, Z. Stratum Ventilation-A Solution to Meet Challenges to Contemporary Air Distribution. Fed. Eur. Heat. Vent. Air Cond. Assoc. 2014, 51, 40-43.

12. Liu, Z.; Liu, Z.; Zuo, Z. Effect of Stratum Ventilation on Thermal Comfort and Energy Utilization Efficiency of Numerical Simulation. Energy Procedia 2017, 105, 3596-3602. [CrossRef]

13. Rajput, U.A.; Mujtaba, M.A.; Yau, Y.H. Stratum Ventilation: A Viable Air Distribution for Nightingale Wards to Reduce the Risk of Airborne Transmission. In Proceedings of the International Conference on Energy, Water and Environment-ICEWE-2021, Lahore, Pakistan, 31 March 2021.

14. Tian, L.; Lin, Z.; Wang, Q. Experimental investigation of thermal and ventilation performances of stratum ventilation. Build. Environ. 2011, 46, 1309-1320. [CrossRef]

15. Nada, S.A.; El-Batsh, H.M.; Elattar, H.F.; Ali, N.M. CFD investigation of airflow pattern, temperature distribution and thermal comfort of UFAD system for theater buildings applications. J. Build. Eng. 2016, 6, 274-300. [CrossRef]

16. Yau, Y.H.; Poh, K.S.; Badarudin, A. A numerical airflow pattern study of a floor swirl diffuser for UFAD system. Energy Build. 2018, 158, 525-535. [CrossRef]

17. Lin, Z.; Chow, T.T.; Tsang, C.F.; Fong, K.F.; Chan, L.S. CFD study on effect of the air supply location on the performance of the displacement ventilation system. Build. Environ. 2005, 40, 1051-1067. [CrossRef]

18. Sui, X.; Zhang, X. Effects of radiant terminal and air supply terminal devices on energy consumption of cooling load sharing rate in residential buildings. Energy Build. 2012, 49,499-508. [CrossRef]

19. Said, Z.; Ghodbane, M.; Tiwari, A.K.; Ali, H.M.; Boumeddane, B.; Ali, Z.M. 4E (Energy, Exergy, Economic, and Environment) examination of a small LFR solar water heater: An experimental and numerical study. Case Stud. Therm. Eng. 2021, $27,101277$. [CrossRef]

20. Szczepanik-Scislo, N.; Schnotale, J. An Air Terminal Device with a Changing Geometry to Improve Indoor Air Quality for VAV Ventilation Systems. Energies 2020, 13, 4947. [CrossRef]

21. Nielsen, P.V. Velocity distribution in a room ventilated by displacement ventilation and wall-mounted air terminal devices. Energy Build. 2000, 31, 179-187. [CrossRef]

22. Kalmár, F. Innovative method and equipment for personalized ventilation. Indoor Air 2015, 25, 297-306. [CrossRef] [PubMed]

23. Hu, S.C. Airflow characteristics in the outlet region of a vortex room air diffuser. Build. Environ. 2003, 38, 553-561. [CrossRef]

24. Zhivov, A.; Skistad, H.; Mundt, E.; Posokhin, V.; Ratcliff, M.; Shilkrot, E.; Strongin, A.; Li, X.; Zhang, T.; Zhao, F.; et al. Chapter 7-Principles of Air and Contaminant Movement Inside and Around Buildings. In Industrial Ventilation Design Guidebook, 2nd ed.; Goodfellow, H.D., Kosonen, R., Eds.; Academic Press: Cambridge, MA, USA, 2020; pp. $245-370$.

25. Nastase, I.; Meslem, A.; Vlad, I.; Colda, I. Lobed grilles for high mixing ventilation-An experimental analysis in a full scale model room. Build. Environ. 2011, 46, 547-555. [CrossRef]

26. Sajadi, B.; Saidi, M.H.; Mohebbian, A. Numerical investigation of the swirling air diffuser: Parametric study and optimization. Energy Build. 2011, 43, 1329-1333. [CrossRef]

27. Sun, Y.; Smith, T.F. Air flow characteristics of a room with square cone diffusers. Build. Environ. 2005, 40, 589-600. [CrossRef]

28. Villafruela, J.M.; Sierra-Pallares, J.B.; Castro, F.; Alvaro, A.; Santiago-Casado, P. Experimental and numerical study of the influence of the plenum box on the airflow pattern generated by a swirl air diffuser. Exp. Therm. Fluid Sci. 2018, 99, 547-557. [CrossRef]

29. Smoljan, D.; Balen, I. Influence of a Plenum Box Design on Uniformity of the Radial Air Jet Issuing from a Vortex Diffuser. Strojarstvo 2010, 52, 379-386.

30. Yao, T.; Lin, Z. An experimental and numerical study on the effect of air terminal types on the performance of stratum ventilation. Build. Environ. 2014, 82, 431-441. [CrossRef]

31. Zhao, H.; Liu, Z.; Zuo, Z. Numerical Simulation of Indoor Thermal Environment Effected by Air Supply Temperature and Grille Angle on Stratum Ventilation in a Typical Office. Procedia Eng. 2015, 121, 779-784. [CrossRef]

32. Cheng, Y.; Lin, Z.; Wu, W.; Yao, T. Performance Evaluation of Stratum Ventilation with Slot Diffuser Using CFD. In 13th International Conference on Indoor Air Quality and Climate; International Society of Indoor Air Quality and Climate: Herndon, VA, USA, 2014.

33. Yao, T.; Lin, Z. Numerical Study of The Effect of Air Terminal Layouts on The Performance of Stratum Ventilation System. In International High Performance Buildings Conference; Purdue University, Purdue e-Pubs: West Lafayette, IN, USA, 2014.

34. ANSI/ASHRAE-62.1; Ventilation for Acceptable Indoor Air Quality. ASHRAE: Peachtree Corners, GA, USA, 2019. 
35. Paul Solberg, J.M.; Guckelberger, D.; Sturm, E. Applying Variable Refrigerant Flow. Trane Engineers Newsletter Series, 2014. Available online: https:/ / www.trane.com/content/dam/Trane/Commercial/global/products-systems/education-training/ continuing-education-gbci-aia-pdh/Variable-Refrigerant-Flow-VRF/APP-CMC051_VRF_Handouts.pdf (accessed on 20 July 2021).

36. Zheng, C.; You, S.; Zhang, H.; Zheng, W.; Zheng, X.; Ye, T.; Liu, Z. Comparison of air-conditioning systems with bottom-supply and side-supply modes in a typical office room. Appl. Energy 2018, 227, 304-311. [CrossRef]

37. Lin, Z.; Yao, T.; Chow, T.T.; Fong, K.F.; Chan, L.S. Performance evaluation and design guidelines for stratum ventilation. Build. Environ. 2011, 46, 2267-2279. [CrossRef]

38. Lin, Z. Effective draft temperature for evaluating the performance of stratum ventilation. Build. Environ. 2011, 46, 1843-1850. [CrossRef]

39. Liu, S.; Novoselac, A. Air Diffusion Performance Index (ADPI) of diffusers for heating mode. Build. Environ. 2015, 87, 215-223. [CrossRef]

40. Yau, Y.H.; Poh, K.S.; Badarudin, A. An investigation of thermal environment of an existing UFAD system in a high-rise office building in the tropics. J. Environ. Health Sci. Eng. 2018, 16, 313-322. [CrossRef] [PubMed]

41. Hashemian, H.M.; Hashemian, M.; Riggsbee, E.T. New Sensor for Measurement of Low Air Flow Velocity, in Analysis and Measurement Services Corporation; Division of Regulatory Applications: Knoxville, TN, USA, 1995.

42. Halibart, J.; Zwolinska, K.; Borowski, M.; Jaszczur, M. Analysis of the Velocity Distribution in the Plenum Box with Various Entries. Energies 2021, 14, 3630. [CrossRef]

43. ASHRAE. ASHRAE Handbook-Fundamentals; ASHRAE: Peachtree Corners, GA, USA, 2017. 